\title{
Review \\ Critical Role of Estrogens on Bone Homeostasis in Both Male and Female: From Physiology to Medical Implications
}

\author{
Emmanuelle Noirrit-Esclassan ${ }^{1,2}$, Marie-Cécile Valera ${ }^{1,2}$, Florence Tremollieres ${ }^{1,3}$, Jean-Francois Arnal ${ }^{1}$, \\ Françoise Lenfant ${ }^{1}$, Coralie Fontaine ${ }^{1}$ and Alexia Vinel ${ }^{1,4}$,*
}

1 I2MC, INSERM UMR 1297, University of Toulouse III, F-31000 Toulouse, France; noirrit.e@odonto-tlse.eu (E.N.-E.); marie.valera@inserm.fr (M.-C.V.); tremollieres.f@chu-toulouse.fr (F.T.); jean-francois.arnal@inserm.fr (J.-F.A.); francoise.lenfant@inserm.fr (F.L.); Coralie.fontaine@inserm.fr (C.F.)

2 Department of Pediatric Dentistry, Faculty of Dental Surgery, University of Toulouse III, F-31000 Toulouse, France

3 Menopause and Metabolic Bone Disease Center, Hôpital Paule de Viguier, University Hospital of Toulouse, F-31000 Toulouse, France

4 Department of Periodontology, Faculty of Dental Surgery, University of Toulouse III, F-31000 Toulouse, France

* Correspondence: alexia.vinel@inserm.fr; Tel.: +33-5-61-77-36-10

Citation: Noirrit-Esclassan, E.; Valera, M.-C.; Tremollieres, F.; Arnal, J.-F.; Lenfant, F.; Fontaine, C.; Vinel, A Critical Role of Estrogens on Bone Homeostasis in Both Male and Female: From Physiology to Medical Implications. Int. J. Mol. Sci. 2021, 22, 1568. https://doi.org/10.3390/ ijms22041568

Academic Editor: Antoine Martinez

Received: 5 January 2021

Accepted: 1 February 2021

Published: 4 February 202

Publisher's Note: MDPI stays neutral with regard to jurisdictional claims in published maps and institutional affiliations.

Copyright: (C) 2021 by the authors. Licensee MDPI, Basel, Switzerland. This article is an open access article distributed under the terms and conditions of the Creative Commons Attribution (CC BY) license (https:/ / creativecommons.org/licenses/by/ $4.0 /)$.

\begin{abstract}
Bone is a multi-skilled tissue, protecting major organs, regulating calcium phosphate balance and producing hormones. Its development during childhood determines height and stature as well as resistance against fracture in advanced age. Estrogens are key regulators of bone turnover in both females and males. These hormones play a major role in longitudinal and width growth throughout puberty as well as in the regulation of bone turnover. In women, estrogen deficiency is one of the major causes of postmenopausal osteoporosis. In this review, we will summarize the main clinical and experimental studies reporting the effects of estrogens not only in females but also in males, during different life stages. Effects of estrogens on bone involve either Estrogen Receptor (ER) $\alpha$ or ER $\beta$ depending on the type of bone (femur, vertebrae, tibia, mandible), the compartment (trabecular or cortical), cell types involved (osteoclasts, osteoblasts and osteocytes) and sex. Finally, we will discuss new ongoing strategies to increase the benefit/risk ratio of the hormonal treatment of menopause.
\end{abstract}

Keywords: bone remodeling; sexual dimorphism; estrogens; estrogen receptor; nuclear effects; ER $\alpha$ MISS

\section{Introduction}

Far from inert, bone is a highly dynamic tissue undergoing constant remodeling regulated by numerous parameters and, among others, estrogens are of major importance. Estrogens are steroidal compounds derived from cholesterol. There are four identified estrogens: $17 \beta$-estradiol (E2), the most powerful and well known, estrone (E1) produced during menopause, estriol (E3) released during pregnancy by the placenta and estetrol (E4) synthesized by fetal liver [1]. In women, E2 is synthetized in the ovaries from puberty to menopause. E2 is responsible for the development of primary and secondary sexual characteristics in women but it is also produced in men via aromatization of testosterone in the testes (20\%) and peripheral tissues (80\%) [2]. It is now admitted that estrogens are key regulators of bone remodeling in both sexes [3]. Although its multifactorial origin is not quite fully elucidated (direct and indirect effects of pubertal sexual steroids, role of autosomal genes), sexual dimorphism of the skeleton mass and architecture is well known: men have wider long bones than women and their vertebrae have a higher bone volume and thus a higher trabecular bone mineral density (BMD). The review aims to describe bone turnover regulation by estrogens and their receptors and the main differences and their common characteristics in both females and males. 


\subsection{Bone Physiology}

Bone is a metabolically active and complex tissue conferring hardness and resistance to the skeleton. It exhibits four major roles: mechanical, since it supports the organism and allows locomotion, protection of vital organs (brain, heart, lungs, etc.) and hematopoietic marrow, metabolic, as the reservoir of calcium, phosphorus and mineral ions and endocrine via the production of osteocalcin and FGF23 [4].

Every bone in the skeleton is made of two types of tissue, cortical bone and trabecular bone. Cortical bone constitutes the compact external wall of every bone as well as the diaphysis of long bones; it represents $80 \%$ of the skeleton. The remaining $20 \%$ is made of trabecular bone, composing the end of long bones and flat bones, and is made of a tridimensional network of interconnected trabeculae surrounded by bone marrow. Bone is a highly specialized connective tissue comprising a mineralized organic substance with an extracellular matrix with collagen fibers and non-collagenic proteins, a calcium hydroxyapatite crystal mineral fraction and bone cells [5].

\subsection{Bone Cells}

Bone contains two main types of highly differentiated cells, the osteoclasts responsible for bone resorption and osteoblasts that are in charge of bone production.

Resulting from the fusion of hematopoietic mononuclear progenitors, osteoclasts are giant multinucleated cells that represent less than $1 \%$ of bone cells. Two molecules are necessary to induce osteoclastogenesis, macrophage colony-stimulating factor (M-CSF) and receptor activator of nuclear factor kappa-B ligand (RANKL) [6]. M-CSF produced by bone marrow stromal cells is essential for the survival and proliferation of osteoclast precursor monocytes/macrophages. RANKL is a resident membrane protein at the surface of osteoblasts, specifically recognized by its receptor RANK present at the surface of bone marrow monocytes/macrophages [6]. Osteoclasts are the only cells able to resorb bone tissue. Activated osteoclasts form a hermetic compartment between themselves and the bone surface in which they release protons and chloride $\left(\mathrm{Cl}^{-}\right)$responsible for bone demineralization. Then, the exposed organic phase is degraded by cathepsin- $\mathrm{K}$ and matrix metalloproteinases that are also secreted by osteoclasts [7].

Osteoblasts are bone-forming cells, accounting for 4 to $6 \%$ of bone-residing cells. They derive from mesenchymal stem cells following the expression of several transcription factors, including RUNX2 and OSX [8]. Mature osteoblasts secrete bone matrix proteins like osteocalcin $(\mathrm{OCN})$, bone sialoproteins I and II and type 1 collagen [9]. During bone formation, osteoblasts are responsible for the secretion of new organic bone matrix and its mineralization $[9,10]$. In addition, they have a paracrine effect on osteoclasts by expressing RANKL and producing M-CSF [10,11].

Osteocytes are the last stage of osteoblastic differentiation; they represent $95 \%$ of bone cells. They are stellate cells with numerous dendritic processes embedded in the mineralized bone matrix. During the transition from mature osteoblasts to osteocytes, the expression of OCN, bone sialoproteins and type I collagen is strongly repressed and new markers such as dentin matrix protein-1 (DMP1) and sclerostin are highly expressed [12]. Osteocytes are mechanosensory cells able to sense and respond to mechanical forces. They are tightly connected to one another via their dendritic processes, which constitute a tridimensional network within the mineralized bone matrix [13].

\subsection{Bone Modeling and Remodeling}

Bone modeling determines the development and maintenance of bone shape during skeletal growth. It starts from the very beginning of fetal bone formation and lasts until the end of skeletal longitudinal growth. Bone remodeling is a life-long process, involving cycles of bone resorption and bone formation; it has a major role in calcium homeostasis, bone adaptation to mechanical stresses and altered bone repair. Bone remodeling is an asynchronous process occurring all over the skeleton to replace micro-damaged bone [14,15]. Schematically, a remodeling cycle follows four steps: 1 -activation of a formerly quiescent 
bone surface and recruitment of osteoclastic precursors; 2 -resorption of damaged bone by mature osteoclasts; 3 -recruitment of preosteoblasts; 4 - new bone formation and mineralization by mature osteoblasts. Bone mass maintenance throughout life is allowed by the strict balance between bone resorption and formation that are linked in time and space. The strict correlation between bone resorption and formation is called coupling, with the formation of an adequate number of osteoblasts at the resorption sites [16].

\section{Skeletal Evolution throughout Life}

Throughout life, bone mass evolves in three phases according to a shifting balance in bone remodeling. During the growth phase, bone formation exceeds bone resorption and osteogenesis predominates. In both males and females, once peak bone mass is reached around the age of 30 years, net bone mass slowly but steadily declines [17]. Because of aging and a decrease in sex hormone secretion, bone resorption becomes higher than bone formation, contributing to osteoporosis and increased fracture risk, more markedly in women after menopause [18]. Estradiol and testosterone evolution curves follow almost the same layout as the bone mineral density evolution curve, which suggests a relationship between both parameters [19].

\subsection{Skeletal Development}

Skeletal mineralization begins during intrauterine life through intramembranous and endochondral ossification and is mainly regulated by the growth hormone/insulin-like growth factor axis $[17,20]$. Bone mineral mass is acquired relatively slowly throughout childhood, with no substantial sex difference in the axial (lumbar spine) or appendicular (radius and femur) skeleton, when adjusted for age, nutrition and physical activity [21]. Estrogen and androgen regulation is at the basis of the development and maturation of the adult skeleton until epiphyseal fusion, usually by the end of the second decade of life [22]. The peak in bone accretion is reached shortly after peak height gain, at $12.5 \pm 0.90$ years in girls and $14.1 \pm 0.95$ years in boys of European ancestry. This asynchrony between the acceleration of standing height and bone mineral content (BMC) or areal bone mineral density (aBMD) is associated with a transiently thinner and less dense cortex with an increased porosity, that may contribute to the male adolescent increased incidence in forearm fractures [21,23].

Peak bone mass (PBM), which is 60 to $80 \%$ genetically determined, is achieved by the end of skeletal development during adolescence and early adulthood, depending on skeletal sites and sex [20]. The National Health and Nutrition Examination Survey 20052014 showed that attainment of peak BMD occurred significantly earlier in the femoral neck than lumbar spine and earlier in females than males (respectively, between 18.7 and 20.1 years and between 20.5 and 23.6 years) [24]. In spite of the similar volumetric bone mineral density between the two genders during young adulthood, the sexual dimorphism is expressed in bone length, BMD and geometry, providing men with a potential advantage in bone mechanical resistance compared to women [25-27]. Men develop wider bones due to greater periosteal expansion and a wider medullary cavity, with higher trabecular volume and cortical porosity than women. However, volumetric BMD is higher in women in the lumbar spine and femoral neck [28,29]. Throughout growth, trabecular bone density increases by way of the thickening of trabeculae and gains in density. These thicker trabeculae may explain the gender and site differences in trabecular volume across adolescence: bone volume per trabecular volume (BV/TV) at the distal radius did not change in girls although it increased in boys [25]. These gender differences are mainly related to the later onset of puberty with a longer duration of prepubertal-predominantly appendicular-growth, and slightly to the greater peak height velocity and the longer duration of the growth spurt in boys compared with girls [28].

Estrogens have a biphasic effect on long bone development, which is induced at low concentrations. However, at high doses, estrogens promote epiphysial closure via direct action on proliferating chondrocytes and thereby stop further growth [30] (Figure 1). In hu- 
mans, the absence of estrogens is associated with unfused growth plates and indeterminate growth [31,32]. Similarly, a young man with an inactivating mutation of estrogen receptor alpha was abnormally tall with unfused epiphyseal growth plates and ongoing growth [33]. Estrogens are also essential for the anabolic action of androgens, as demonstrated in aromatase-deficient men who showed osteopenia and unfused epiphyses [3,34].
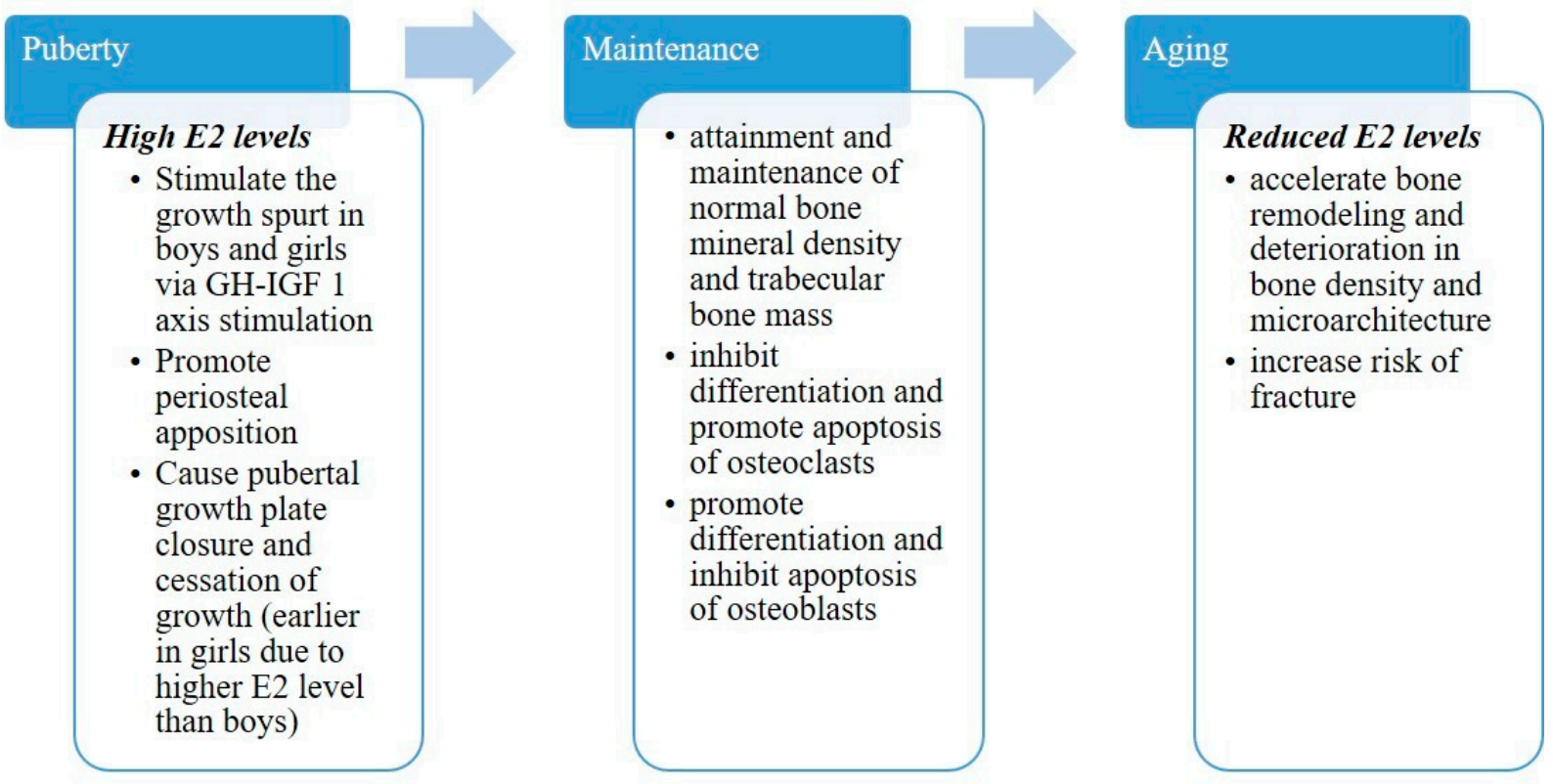

Figure 1. Roles of estrogen in women and men throughout life. (E2: 17 $\beta$-estradiol).

Peak bone mass is one of the most important predictors for bone strength and osteoporotic fracture risk later in life. Bone mass acquired at the end of the growth period appears to be more important than bone loss occurring during adult life [35].

\subsection{Skeletal Maintenance}

During the maintenance phase, estrogens and androgens have a slowing effect on osteoclast and osteoblast differentiation and therefore bone remodeling. Bone formation and resorption are in balance. In normal human adults, the remodeling process in a particular site lasts between 6 and 9 months and 10\% of the skeleton is replaced every year [36]. Testosterone continues to stimulate periosteal growth, whereas estrogens are important for the maintenance of trabecular bone mass and structure [37]. During the third decade, cortical modeling of long bones with ongoing cortical mineralization, decreasing porosity and endosteal contraction contribute to bone consolidation in men [38,39]. The cortical bone area continues to increase until age 60-70 in men. Conversely, in women, cortical perimeter and bone strength do not increase [38]. Endosteal expansion is greater from age 50 and causes bone loss in older women despite periosteal apposition.

During adulthood, some endocrine pathologies involving estrogens, like complete androgen insensitivity syndrome (CAIS), due to complete androgen resistance, or premature ovarian insufficiency or Turner syndrome, can lead to decreased BMD in women at the lumbar level and at the femoral neck $[40,41]$. Bone loss associated with estrogen deficiency following menopause is greater in trabecular than in cortical bone [42].

\subsection{Pregnancy and Lactation}

Female bone physiology must adapt to meet the calcium needs of the fetus during pregnancy and then during lactation. During pregnancy, the peak of fetal requirement for minerals occurs in the third trimester. The predominant maternal adaptation to fetal requirement is based on a twofold increase in intestinal calcium absorption. Estrogens increase up to 100-fold during pregnancy but the effects of these hormones on bone 
homeostasis in pregnant women have been under-explored [43]. Most human data indicate a neutral effect of pregnancy on the maternal skeleton or even greater BMD in long bone $[43,44]$. Moreover, there is a positive association between the number of pregnancies and fracture risk at the beginning of menopause, as fracture risk reduction becomes statistically significant after three pregnancies [45].

In contrast to pregnancy, the main adaptation during lactation is a temporary demineralization of the skeleton with osteoclast-mediated bone resorption and osteocytic osteolysis. This increased bone turnover is hormonally programmed with reduced estrogen levels and increased Parathyroid Hormone-related protein (PTHrp) levels in breast milk, and is independent of dietary calcium intake. This transient bone loss is reversed after weaning, with a neutral or even protective effect of breastfeeding against low BMD and fragility in long bone, unless exclusive breastfeeding is extended [46,47].

Most studies in pregnant or breastfeeding women explored peripheral bones. However, some studies reported vertebrae osteoporosis and spinal fractures in pregnant women. Even if pregnancy- or lactation-related osteoporosis is rare, it can cause severe back pain, height loss and disability. The prevalence, etiology and physiopathology of this disease are still poorly defined and require further investigation [48-50].

\subsection{Skeletal Involution}

BMD along with cortical and cancellous bone mass progressively decline from the fourth decade [51]. Bone loss occurs in response to both estrogen and androgen deficiency and cellular senescence. In women, bone loss is markedly accelerated during the menopause transition, a 3-year period around the final menstrual period, and continues at a lower rate, whereas it is more gradual in men [18,52-54]. It may lead to osteoporosis, a skeletal disorder characterized by compromised bone strength predisposing to an increased risk of fracture [51]. In menopausal women, the loss of cancellous bone in the spine accelerates more than in the hip and total body [28]. Men have markedly stronger bones and a lower incidence of osteoporotic fractures because of higher PBM and greater long bone width, along with lower bone loss later in life [28].

\subsection{Sex Steroid Deficiency}

In women, the abrupt decline in serum estradiol levels through menopause is closely associated with an increased osteoclastic bone resorption. Low estrogen levels in postmenopausal women stimulate circulating macrophages to produce osteoclastic cytokines that activate RANK and promote osteoclast activation [17]. Moreover, the loss of the direct pro-apoptotic effects of estrogens on osteoclasts results in the prolongation of osteoclast lifespan, leading to the acceleration of trabecular bone loss [55].

A late menarche or an early menopause has been associated with a significantly higher risk of hip fracture. After adjustment for other variables, a relatively earlier menarche was associated with a slightly better protective effect than a relatively later menopause, whereas late puberty was associated with non-maximum bone acquisition and higher fracture risk $[21,56-58]$. The Women's Health Initiative Observational Study concluded that higher bioavailable estradiol and testosterone in postmenopausal women were associated with a decreased risk of osteoporotic fracture [59]. Conversely, bone loss in men is more due to decreased osteogenesis, which results in thinner, less perforated trabeculae, which are more widely spaced compared to those of postmenopausal women. Estrogens are key regulators of bone metabolism not only in women but also in men. Their declined serum level with age in men are correlated with decreasing BMD levels $[60,61]$ (Figure 1). Interestingly, genderaffirming hormone therapy (GAHT) in trans women (with estradiol and antiandrogens) and in trans men (with testosterone) resulted in increased bone turnover in younger trans men whereas it decreased in trans women and older trans men (postmenopausal), showing the crucial role of estrogen in bone resorption regulation [62]. In men, fractures have been shown to be inversely associated with bioavailable free testosterone (but not with total testosterone) when the sex hormone-binding globulin (SHBG) level was high [63]. 


\subsection{Aging}

Bone resorption results from increased osteocyte apoptosis, a reduced number of osteoblast precursors and stem cells from which these precursors are derived or reduced osteoblast lifespan $[19,36]$. Additionally, increased glucocorticoid production and sensitivity with advancing age decrease skeletal hydration and thereby increase skeletal fragility [36].

With aging, cortical porosity increases more in women than in men, while trabecular thickness declines more in men than in women, and bone expansion at the periosteal surface increases more in men than in women so that the total bone area becomes larger in men than in women [64]. Older women show dramatically greater medullary expansion and cortical thinning, due to endocortical resorption outpacing periosteal apposition [65].

\section{Roles of Estrogen Receptors}

\subsection{Estrogen Receptors}

Estrogen effects are mediated by two receptors, estrogen receptors alpha $(\mathrm{ER} \alpha)$ and beta $(E R \beta)$. Encoded by gene esr 1 and cloned in 1986, ER $\alpha$ has been considered as the unique receptor for estrogens until the discovery and cloning of ER $\beta$, encoded by gene esr2, ten years later [66-69]. Although structurally closely related, expression patterns of estrogen receptors are different since ER $\alpha$ is widely expressed not only in reproductive organs in females and males (uterus, mammary gland, testes, epididymis) but also in non-reproductive organs such as the liver, heart and muscles; ER $\beta$ is mainly expressed in ovaries and the prostate gland. However, both receptors are expressed in bone tissue $[2,70]$. As members of the nuclear receptor superfamily, ER $\alpha$ and ER $\beta$ present six structural domains, A to F, a DNA-binding domain (DBD) and a ligand binding domain (LBD), as well as two Activating Functions, AF1 and AF2, involved in cofactor recruitment and in fine chromatin remodeling and gene transcription [71].

Murine models, deficient for ER $\alpha$ and ER $\beta$, have allowed the study of the respective roles of each receptor in bone tissue. Results from the first studies, published in the early 2000s, have to be considered with caution since the murine model initially used $(\mathrm{ER} \alpha$ and $\mathrm{ER} \beta-\mathrm{Neo}-\mathrm{KO})$ are not complete functional knockouts and still express truncated forms of ER $\alpha$ able to bind E2 [72,73]. New models, totally deficient in ER $\alpha\left(E R \alpha^{-/-}\right)$ and $\operatorname{ER} \beta\left(E R \beta^{-/-}\right)$, have since been developed [74]. A first study in intact female and male mice showed that ER $\alpha$ deletion was associated with reduced bone turnover and increased trabecular bone volume in both genders. ER $\beta$ deletion had the same effects but only in female mice and the deletion of both receptors caused a drop in trabecular bone volume and turnover. ER $\alpha^{-/-}$mice exhibited strongly increased levels of circulating E2 and testosterone in females and males, resulting from a profound disruption of endocrine feedback loops [75]. To better understand the effects of ER deletion, gonadectomy was performed and associated with a reduction in all bone parameters (BMD, BV/TV, cortical thickness) and an increased bone turnover. E2 systemic administration could not restore bone features in $\mathrm{ER} \alpha^{-/-}$female and male mice in contrast to wildtype (WT). In contrast, $\mathrm{ER} \beta^{-/-}$mice had a similar response to E2 as WT [76], showing the prominent role of ER $\alpha$ in bone responses to estrogen in both males and females, while ER $\beta$ only has a minor protective role in females and none in males [75,76] (Figure 2). As in long bones and vertebrae, ER $\alpha$ is also necessary for E2's protective effects in the mandible at alveolar, cortical and trabecular sites, whereas ER $\beta$ is dispensable [77]. ER $\alpha \beta^{-/-}$mice, allowing the study of the possible compensatory role of one ER or the other in single-gene $\mathrm{KO}$ models $\left(E R \alpha^{-/-}\right.$and $\left.E R \beta^{-/-}\right)$, exhibit a similar bone phenotype to $E R \alpha^{-/-}$mice, showing that $\mathrm{ER} \beta$ is not sufficient to compensate for $\mathrm{ER} \alpha$ actions in $\mathrm{ER} \alpha^{-/-}$mice and that $\mathrm{ER} \alpha$ is truly the central actor in estrogen osteoprotective effects [76]. 


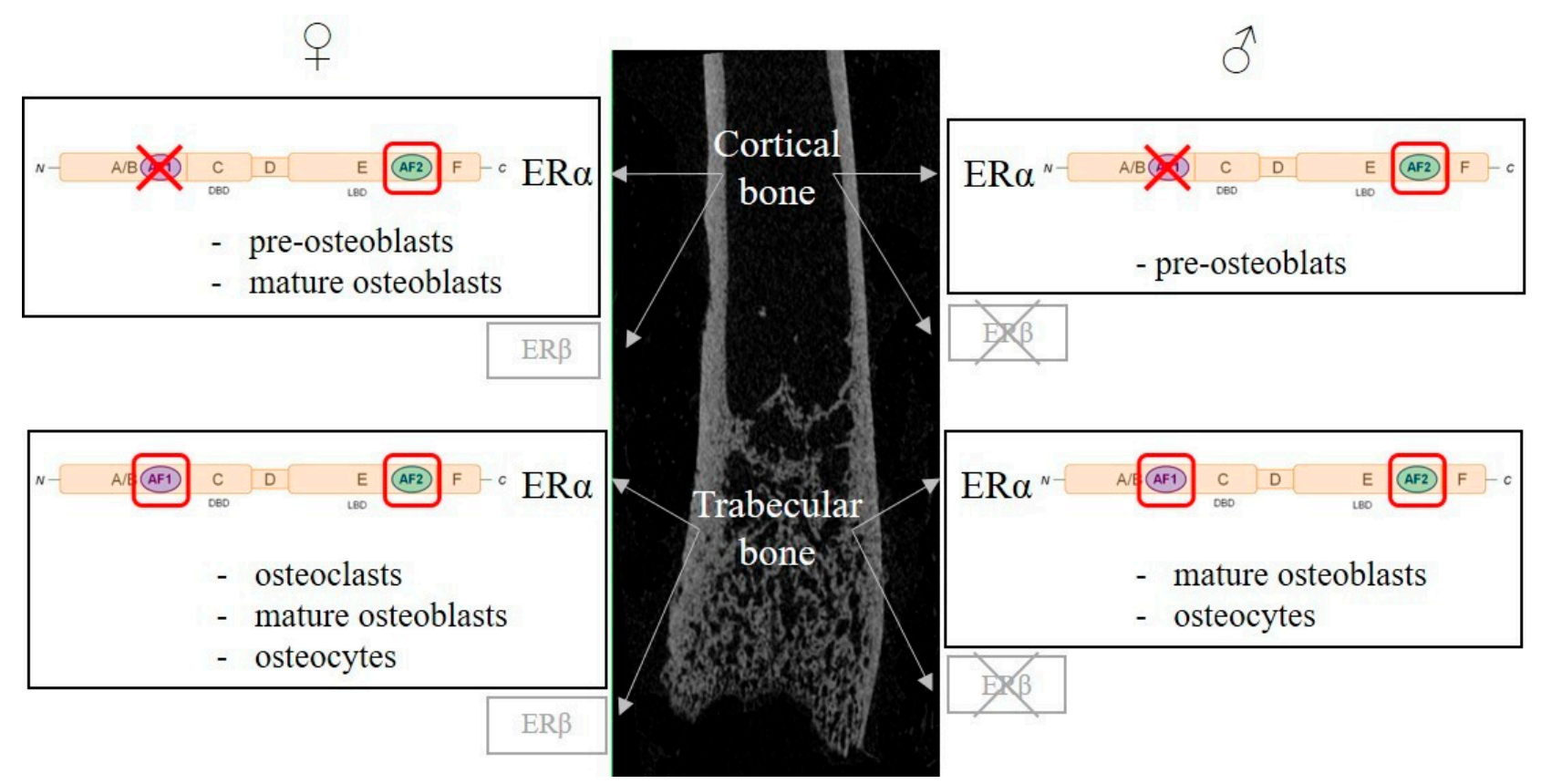

Figure 2. Regulation of bone metabolism by estrogen receptors, cellular and molecular aspects. Estrogen's protective effects on trabecular and cortical bone are mainly mediated by Estrogen Receptor $\alpha$ (ER $\alpha)$ in both females and males, while $\mathrm{ER} \beta$ only plays a minor role in female and none in male. ER $\alpha$ belongs to the nuclear receptor superfamily and exerts its transcriptional activity though two activating functions (AFs), AF1 and AF2. Both AF1 and AF2 functions are necessary to mediate estrogen effects, whereas, in the cortical compartment, only AF2 function is necessary in females and males. Genetic murine models have allowed the study of the role of ER $\alpha$ in bone cells (osteoclasts, osteoblasts and osteocytes). For each bone compartment and sex, the cell types involved in estrogen's protective effects are indicated. A red box highlights essential ER $\alpha$ subfunctions in each cell type, whereas a red X indicates the dispensable ER $\alpha$ subfunction.

However, constitutive ER $\alpha$ inactivation could lead to important developmental changes that may alter the adult mouse phenotype, although ER $\alpha$ appears to play a minor, if any, role in the development of most tissues, including those of the reproductive organs. To avoid this bias and study the $\mathrm{E} 2$ actions on ER $\alpha$ in adults, a team recently used an ER $\alpha$-deficient tamoxifen-inducible mouse model [78]. In this model, trabecular responses to E2 treatment after ovariectomy and bone turnover are reduced but cortical response is maintained. Normal cortical responses to E2 in mutant mice may be explained by ER $\beta$ involvement either locally in bone tissue or by indirect effects in other tissues. For instance, estrogen receptors are expressed in several brain regions, and E2 is able to regulate cortical bone mass in female mice via indirect central nervous system mechanisms [79,80].

\subsection{Estrogen Receptors in Bone Cells}

The development of mouse models with conditional targeted deletion of ERs using the Cre-loxP system allowed the definition of more precise estrogen cellular targets in bone physiology. The expression of a Cre-recombinase controlled by the promotors of genes expressed specifically in targeted cell types or tissues results in the deletion of a genomic region of interest (here, crucial sequences of Esr1 or Esr2) flanked by two LoxP sites. Several models have been used to mainly study the role of ER $\alpha$ but also that of ER $\beta$ in bone cells (Table 1, Figure 2). 
Table 1. ER $\alpha$ role in bone cells and the impact of its selective deletion in trabecular and cortical bone compartments in female and male mice.

\begin{tabular}{|c|c|c|c|c|c|c|c|c|c|c|c|c|c|c|}
\hline \multirow{2}{*}{$\begin{array}{c}\text { Targeted Cells } \\
\begin{array}{c}\text { Differentiation } \\
\text { Stage }\end{array}\end{array}$} & \multicolumn{4}{|c|}{ Osteoclasts } & \multicolumn{8}{|c|}{ Osteoblasts } & \multicolumn{2}{|c|}{ Osteocytes } \\
\hline & \multicolumn{2}{|c|}{$\begin{array}{l}\text { Myeloid } \\
\text { Progenitors }\end{array}$} & \multicolumn{2}{|c|}{$\begin{array}{c}\text { Mature } \\
\text { Osteoclasts }\end{array}$} & \multicolumn{2}{|c|}{$\begin{array}{l}\text { Pluripotent } \\
\text { Mesenchymal } \\
\text { Progenitors }\end{array}$} & \multicolumn{2}{|c|}{$\begin{array}{l}\text { Osteoblastic } \\
\text { Progenitors }\end{array}$} & \multicolumn{2}{|c|}{$\begin{array}{c}\text { Mature Matrix } \\
\text { Maturation }\end{array}$} & \multicolumn{2}{|c|}{$\begin{array}{c}\text { Mature } \\
\text { Mineralization }\end{array}$} & NA & \\
\hline gene promotor & \multicolumn{2}{|c|}{ LysM } & \multicolumn{2}{|c|}{$C t s K$} & \multicolumn{2}{|c|}{$\operatorname{Prx} 1$} & \multicolumn{2}{|c|}{ Os $x 1$} & \multicolumn{2}{|c|}{ Col1a1 } & \multicolumn{2}{|c|}{ Ocn } & \multicolumn{2}{|c|}{ Dmp1 } \\
\hline gender & female & male & female & male & female & male & female & male & female & male & female & $\underset{\leftrightarrow}{\operatorname{male}}$ & $\begin{array}{l}\text { female } \\
\leftrightarrow\end{array}$ & male \\
\hline trabecular bone & $\searrow$ & $\leftrightarrow$ & $\searrow$ & $\leftrightarrow$ & $\leftrightarrow$ & $\leftrightarrow$ & $\leftrightarrow$ & $\leftrightarrow$ & $\leftrightarrow$ & $\leftrightarrow$ & $\searrow$ & $\begin{array}{c}{[81]} \\
\searrow \\
{[82]}\end{array}$ & $\begin{array}{c}{[83]} \\
\searrow \\
{[84]}\end{array}$ & $\searrow$ \\
\hline $\begin{array}{c}\text { cortical bone } \\
\text { references }\end{array}$ & $\begin{array}{c}\leftrightarrow \\
{[55]}\end{array}$ & $\begin{array}{c}\leftrightarrow \\
{[85]}\end{array}$ & $\begin{array}{c}\leftrightarrow \\
{[86]}\end{array}$ & $\begin{array}{c}\leftrightarrow \\
{[86]}\end{array}$ & $\begin{array}{c}\searrow \\
{[87]}\end{array}$ & $\begin{array}{l}\searrow * \\
{[87]}\end{array}$ & $\begin{array}{c}\searrow \\
{[87]}\end{array}$ & $\begin{array}{c}\searrow * \\
{[85]}\end{array}$ & $\begin{array}{c}\leftrightarrow \\
{[87]}\end{array}$ & $\begin{array}{c}\leftrightarrow \\
{[87]}\end{array}$ & $\begin{array}{c}\searrow \\
{[81,82,} \\
88]\end{array}$ & $\begin{array}{l}\overleftrightarrow{\leftrightarrow} \\
{[81,} \\
82]\end{array}$ & $\begin{array}{l}\overleftrightarrow{\leftrightarrow} \\
{[83,} \\
84]\end{array}$ & $\begin{array}{c}\leftrightarrow \\
{[83]}\end{array}$ \\
\hline
\end{tabular}

$\leftrightarrow$ no effect; \ $\searrow$ bone mass reduction; * transient effect.

The deletion of ER $\alpha$ under the control of the cathepsine K (CtsK) promoter, specifically expressed in mature osteoclasts, was associated with trabecular bone loss in 12-week-old female mice but not in males [86]. Ovariectomy caused minor supplemental bone loss and E2 treatment restored trabecular bone mass but had no impact on the cortical compartment. Trabecular bone mass reduction was associated in $\mathrm{CtsK}-\mathrm{Cre}^{+} \mathrm{Er} \alpha^{\text {lox }} / \mathrm{lox}$ mice with increased osteoclast number and bone turnover in trabecular bone. A second model targeting myeloid osteoclast precursors under the control of the lysozyme M (LysM) promoter showed similar results. While female mutated mice exhibited an increased number of osteoclastic progenitors in bone marrow and differentiated osteoclasts in vertebrae, they had altered trabecular bone mass and microarchitecture, but no effect was observed in cortical bone [55]. In contrast, LysM-Cre ${ }^{+} E R \alpha^{\text {lox } / l o x}$ males had a similar bone phenotype to WT mice in both trabecular and cortical compartments [85].

$\mathrm{ER} \alpha$ deletion in mesenchymal pluripotent osteoblast progenitors under the control of the Prx 1 gene promoter (thus in all the following differentiation stages) was characterized by reduced cortical bone thickness and periosteal bone formation in female mice [87]. In contrast to WT mice, ovariectomy in Prx1-Cre ${ }^{+} \mathrm{ER} \alpha^{\text {lox}} / \mathrm{lox}$ female mice did not induce supplemental cortical bone loss and was not associated with increased osteoclast number at the endocortical bone surface in femurs. In male mice, cortical bone mass was transitorily reduced at 8 weeks of age but was similar to WT at 22 weeks of age. Trabecular bone was unaffected in mutant females and males. Bone marrow cellular culture from Prx1$\mathrm{Cre}^{+} \mathrm{ER} \alpha^{\text {lox/lox }}$ mice showed reduced osteoblast number and activity as evidenced by reduced expression of osteoblast differentiation markers Runx2, Osx, Col1a1 and Bglap [87]. $E R \beta$ deletion at the same stage of osteoblastic differentiation was associated with increased trabecular bone mass in female mice [89]. Female mice with ER $\alpha$ inactivation at a more advanced differentiation stage, in osteoblast progenitors present in bone-forming regions, under the control of the Osx1 (also called Sp7) gene promotor, had a similar bone phenotype and osteogenesis alteration [87]. Male Osx1-Cre ${ }^{+} E R \alpha^{\text {lox} / l o x}$ mice also had transiently reduced cortical bone mass and trabecular bone was not affected [85]. Transiently reduced cortical bone mass in males seems to reflect a delay in cortical bone mass acquisition during puberty since adult mice have normal cortical bone mass, suggesting that the action of androgens mediated by androgen receptors compensates for the absence of ER $\alpha$. Finally, the targeted deletion of ER $\alpha$ in terminal osteoblastic differentiation in mature osteoblasts and osteocytes, controlled by the Col1a1 gene promoter, had no effect on trabecular and cortical bone in neither female nor male mice [87]. However, other teams invalidated ER $\alpha$ in mature osteoblasts using a different gene promoter encoding for $\mathrm{OCN}$, and had different results $[81,82,88]$. In these studies, mutant female mice exhibited reduced trabecular bone mass and cortical thickness in femurs, tibia and vertebrae and reduced bone turnover marked by a limited number of osteoblasts and osteoclasts. No effect of ER $\alpha$ inactivation 
was observed in male mice $[81,82,88]$. These discrepancies may be explained by the use of different $C r e$ models in which promoters are engaged in different chronological expression cellular effects. The Col1a1-Cre model targets osteoblasts during bone matrix maturation and Ocn-Cre targets osteoblasts later on, during bone matrix mineralization. Finally, ER $\alpha$ inactivation in osteocytes using Dmp1-Cre was associated with conflicting results [83,84]. One study found reduced trabecular bone mass and no cortical alteration [84], whereas another showed no bone phenotype in intact 12-week-old female mice [83]. This difference may be explained by the use of ER $\alpha$-floxed mice with different genetic backgrounds. Moreover, it is important to stress that a recent study using flow cytometry and highresolution microscopy showed that Ocn-Cre and Dmp1-Cre models do not only target mature osteoblasts and osteocytes but also affect broader stromal cell populations than initially considered. Results from Ocn-Cre+ER $\alpha^{\text {lox } / \text { lox }}$ and Dmp1-Cre ${ }^{+} E R \alpha^{\text {lox } / \text { lox }}$ mice must then be interpretated with caution [90].

An alternative approach to study the role of $E R \alpha$ in bone tissue consists in the use of hematopoietic chimeras. The reconstruction of lethally irradiated $\mathrm{ER} \alpha^{-/-}$mice with bone marrow from $E R \alpha^{+/+}$mice shows that $\mathrm{ER} \alpha$ is necessary in non-hematopoietic cells, including osteoblasts, to mediate $\mathrm{E} 2$ effects on trabecular and cortical bone compartments [91]. A reverse bone marrow transplant from $\mathrm{ER} \alpha^{-/-}$into WT mice showed that E2 effects on cortical and trabecular bone are enhanced by ER $\alpha$ in the hematopoietic compartment, suggesting that ER $\alpha$ expression in hematopoietic cells potentiates E2 bone-protective effects but only in the presence of ER $\alpha$ in non-hematopoietic cells [91]. Conflicting results with cell-specific inactivation of ER $\alpha$ using the Cre-Lox system may be explained by the fact that bone marrow transplants involve other cells than osteoblasts and osteoclast precursors. Indeed, several cell types of hematopoietic origin, beside osteoclasts, are involved in the estrogenic regulation of bone mass, including T and B lymphocytes [92,93]. A recent study showed that E2 effects on T lymphocytes are indirect since specific ER $\alpha$ deletion under the control of the $L c k$ gene promoter had no effect on trabecular and cortical bone responses to ovariectomy and E2 treatment in female mice [94]. Moreover, mice with a deletion of $\mathrm{ER} \alpha$ specifically in B lymphocytes have a similar bone phenotype to normal controls [95]. Results from the last two studies show that $\mathrm{ER} \alpha$ signaling in $\mathrm{T}$ and $\mathrm{B}$ cells seems to be dispensable for bone loss caused by estrogen deficiency and that E2 effects on bone do not directly target those cells types and are more likely to be indirect.

The use of conditional deletion mice models of ER $\alpha$ in different bone cells showed that estrogen's protective effects on trabecular and cortical bone compartments involve different cell types. E2 bone-protective effects on trabecular bone are mediated via direct actions on osteoclasts in female mice. ER $\alpha$ in osteoblast progenitors has a major role in cortical bone mass acquisition in female mice, whereas ER $\alpha$ in osteoblast mesenchymal precursors is involved in estrogen's protective actions against endocortical bone resorption.

\subsection{Nuclear vs. Non-Nuclear Er $\alpha$-Mediated Pathways}

In its inactive state, ER $\alpha$ is distributed in the nucleus, cytoplasm and plasma membrane in varying proportions, depending cell type. Ligand fixation on the receptor induces two major signaling pathways, nuclear/genomic ER $\alpha$ and membrane/non-genomic ER $\alpha$.

In nuclear-initiated pathways, ligand fixation induces ER $\alpha$ dimerization and translocation to the nucleus, but in numerous cells, significant amounts of ER $\alpha$ appear to be present in the nucleus even in the absence of any ligand. In the nucleus, the ER $\alpha$ dimer interacts with specific promotors of target genes on precise sequences called estrogen response elements (EREs; ERE-dependent, "classical" pathway) or in interaction with other transcription factors such as AP-1 or SP1 bound to very specific DNA sequences (ERE-independent pathway). A third nuclear-initiated pathway is ligand independent, as ER $\alpha$ can be indirectly activated by growth factors like EGF or IGF-1. The fixation to their respective transmembrane receptor activates intracellular kinases able to phosphorylate ER $\alpha$, modulating its interactions with specific cofactors [71]. ER $\alpha$ AF1 and AF2's transactivating functions are able to act either synergically or independently to control 
target gene transcription. AF1 and AF2's activities are finely controlled by transcription cofactor availability, cell type and the nature of the regulated promotor [71]. In order to study the respective roles of AF1 and AF2, mice models lacking one or the other have been developed [96,97]. In bone tissue, ER $\alpha \mathrm{AF} 1$ is necessary to mediate E2's protective effects on trabecular bone in both females and males but is only partly necessary in the cortical compartment. ER $\alpha \mathrm{AF} 2$ is necessary in both the cortical and trabecular compartment to elicit full E2 effects in vertebrae and femurs in both genders; in the mandible, E2's effects on alveolar, trabecular and cortical compartments are also mediated by ER $\alpha \mathrm{AF} 2$ when a dose effect can be studied precisely thanks to an appropriate pellet to deliver accurate E2 doses [77,98-100] (Table 2, Figure 2).

Table 2. Genetic and pharmacological approaches to study the roles of ERs and their subfunctions in bone tissue regulation.

\begin{tabular}{ccccccccc}
\hline & \multicolumn{7}{c}{ Trabecular Bone } & \multicolumn{2}{c}{ Cortical Bone } & \multicolumn{2}{c}{ Alveolar Bone } \\
\hline $\begin{array}{c}\text { Mouse } \\
\text { Model }\end{array}$ & Treatment & Female & Male & Female & Male & Female & Male & References \\
\hline \multirow{2}{*}{ WT } & E2 & $\nearrow \nearrow$ & $\nearrow \nearrow$ & $\nearrow \nearrow$ & $\nearrow \nearrow$ & $\nearrow \nearrow$ & NT & {$[76,77]$} \\
\cline { 2 - 10 } & EDC & $\leftrightarrow$ & NT & $\nearrow$ & NT & $\nearrow$ & NT & {$[77,101]$} \\
\cline { 2 - 10 } & $\mathrm{PaPEs}$ & $\mathrm{NT}$ & $\mathrm{NT}$ & $\mathrm{NT}$ & $\mathrm{NT}$ & $\nearrow$ & $\mathrm{NT}$ & {$[77]$} \\
\hline $\mathrm{ER} \alpha^{-/-}$ & $\mathrm{E} 2$ & $\leftrightarrow$ & $\leftrightarrow$ & $\leftrightarrow$ & $\leftrightarrow$ & $\leftrightarrow$ & $\mathrm{NT}$ & {$[76,77]$} \\
\hline $\mathrm{ER} \beta^{-/-}$ & $\mathrm{E} 2$ & $\nearrow$ & $\nearrow \nearrow$ & $\nearrow$ & $\nearrow \nearrow$ & $\nearrow \nearrow$ & $\mathrm{NT}$ & {$[76,77]$} \\
\hline $\mathrm{ER} \alpha \mathrm{AF} 1^{\circ}$ & $\mathrm{E} 2$ & $\leftrightarrow$ & $\leftrightarrow$ & $\nearrow \nearrow$ & $\nearrow \nearrow$ & $\mathrm{NT}$ & $\mathrm{NT}$ & {$[98,99]$} \\
\hline $\mathrm{ER} \alpha \mathrm{AF} 2^{\circ}$ & $\mathrm{E} 2$ & $\leftrightarrow$ & $\leftrightarrow$ & $\leftrightarrow$ & $\leftrightarrow$ & $\leftrightarrow$ & $\mathrm{NT}$ & {$[77,98,99]$} \\
\hline $\mathrm{C} 451 \mathrm{~A}-\mathrm{ER} \alpha$ & $\mathrm{E} 2$ & $\nearrow$ & $\nearrow$ & $\nearrow$ & $\nearrow$ & $\nearrow$ & $\mathrm{NT}$ & {$[77,102$,} \\
\hline
\end{tabular}

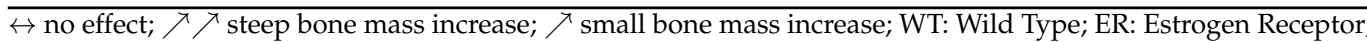
AF: Activcating Function; E2: 17 $\beta$-estradiol; EDC: estrogen-dendrimer conjugate; PaPEs: pathway preferential estrogens; NT: not tested.

Besides classically described nuclear effects, ER $\alpha$ signaling pathways can be initiated at the plasma membrane (membrane-initiated steroid signaling, MISS). Membrane signaling of steroid receptors has been shown in several cell types, including osteoblasts and osteoclasts [104]. Two murine models have been developed to investigate the physiological roles of ER $\alpha$-MISS in vivo. The first one consists in a point mutation of ER $\alpha$ at its palmitoylation site, necessary for its addressing to the plasma membrane, and C451A-ER $\alpha$ mice exhibit a membrane-specific loss of function of ER $\alpha[105,106]$. Two studies show that in the axial skeleton, E2's effects on trabecular bone are strongly dependent on membrane $\mathrm{ER} \alpha(\mathrm{mER} \alpha)$ whereas in long bones, cortical and trabecular E2's effects are only partly dependent on $\mathrm{mER} \alpha$ in growing and adult female mice [102,103]. Moreover, ER $\alpha$-MISS seems to impact osteoblasts but not the osteoclast lineage in response to E2 [102]. In the mandible, bone response to E2 treatment is slightly but significantly reduced in alveolar, trabecular and cortical compartments [77]. These results show that $\mathrm{mER} \alpha$ is necessary to elicit full E2 bone-protective effects. The second model, R264A-ER $\alpha$, consisting in a point mutation of ER $\alpha$ in a sequence necessary for its interaction with proteins at the plasma membrane, is fertile in contrast to C451A-ER $\alpha$ but unable to display classical membraneinitiated E2 effects (accelerated reendothelialization, arterial dilation) [107]. Surprisingly, R264A-ER $\alpha$ mice exhibit similar bone responses to ovariectomy and E2 treatment to WT (BMD, cortical thickness, trabecular bone mass) [108]. Thus, it seems that the functional consequences of this second ER $\alpha$ point mutation appear to be restricted to endothelial cells, without impacting on the $\mathrm{mER} \alpha$ in other cell types.

Besides the use of genetically modified models, another approach to study the respective roles of nuclear and membrane ER $\alpha$ is pharmacological. Despite a weak agonist activity for $E R \alpha$ and $E R \beta$, estetrol (E4), an estrogen produced by fetal liver, has similar effects to E2 on uterine gene expression and epithelial proliferation when administered 
in high doses to female mice and prevents atheroma. All these E4 actions are known to involve nuclear ER $\alpha$ action, whereas E4 is unable to activate endothelial (NOS) and to accelerate endothelial healing, which are MISS-dependent effects [109-112]. Thus, E4 is classified as a natural estrogen with selective action in tissues (NEST) displaying nuclear ER $\alpha$ activation only. E4 administration to osteoporotic female rats was associated to increased bone mineral density and bone strength in a dose-dependent manner [113]. E4 has been studied in human trials as a candidate for menopause hormonal therapy; besides estrogenic effects on reproductive tissues (vaginal epithelium, endometrium) and hot flushes, it has dose-dependent estrogenic effects on bone with a reduction of osteocalcin (bone formation marker) and CTX-1 (bone resorption marker) serum concentrations in postmenopausal women $[1,114,115]$. As part of studies regarding prostate cancer, E4 administration to healthy men reduces bone turnover markers, although not significantly for osteocalcin [116].

While E4 activates ER $\alpha$ nuclear pathways, two other chemical compounds are able to only elicit ER $\alpha$ MISS, estrogen-dendrimer conjugate (EDC) and pathway preferential estrogens (PaPEs). EDC consists of ethinyl-estradiol attached to a large, positively charged, nondegradable poly(amido)amine dendrimer preventing it from translocating to the nucleus [117]. EDC promotes endothelial protection in mice since it increases NO production and accelerates reendothelization without inducing uterine or breast cancer growth [118]. In bone tissue, EDC administration is associated with increased femoral and vertebral cortical bone mass and bone strength. However, it does not seem to have effects on vertebral trabecular bone in either female or male mice [101,119]. In the mandible, EDC increases alveolar bone mass but has no effects on trabecular and cortical bone [77]. More recently, PaPEs originating from the rearrangement of E2 steroidal structure have been developed. PaPEs form complexes with ER with a very short lifespan, sufficient to selectively activate membrane-initiated ER pathways but too transient to maintain nuclear activity; they exert beneficial effects in metabolic tissues and the vasculature [120]. PaPEs have similar effects on mandibular bone to EDC, with increased alveolar bone mass and no effects on trabecular and cortical bone in female mice [77]. PaPEs' effects on vertebral and femoral bone in both females and males have not been determined yet.

Results from genetical approaches targeting nuclear loss-of-function ER $\alpha$-AF ${ }^{\circ}$ on the one hand, and pharmacological approaches with EDC and PaPEs on the other hand, may seem contradictory. Selective activation of ER $\alpha$ MISS with EDC has effects on long and mandibular bone $[77,101]$ while E2's beneficial actions are totally abrogated in nuclear $\mathrm{ER} \alpha$-AF $2^{\circ}$-deficient mice [99]. Nevertheless, it has been shown that nuclear ER $\alpha$-AF1 is necessary for EDC effects, emphasizing the importance of the crosstalk between nuclear and membrane ERs to relay estrogen's beneficial effects on bone [121]. Moreover, one can imagine that part of EDC and PaPEs' actions could involve an activation of both AF1 and AF2, implying another level of interaction between nuclear and membrane ER $\alpha$.

\subsection{Selective Estrogen Receptor Modulators}

Depending on the ligand nature, ERs adopt a specific conformation. Following the fixation of an agonistic ligand such as E2, the position of helix 12 determines the formation of an AF2 region available for transcriptional coactivators to bind on to. In contrast, when an antagonist binds to the receptor, the helix 12 position blocks cofactor recruitment and prevents gene transcription. Between those extremes, the receptor-ligand complex adopts a unique conformation for each ER ligand [71]. Selective estrogen receptor modulators (SERMs) are synthetic pharmacological compounds, lacking an estrogen steroidal structure but exhibiting a tertiary structure, able to bind onto ERs; they can selectively elicit estrogen's protective effects (on bone tissue, the cardiovascular system or metabolism) without triggering deleterious impacts (after menopause, on uterus or mammary glands). Several SERMs are thus employed in clinical practice to treat and prevent breast cancer, osteoporosis or menopause symptoms [122,123]. Tamoxifen (Tam), was developed in the 1970s for breast cancer treatment. It increases cortical and trabecular bone mass in both 
female and male intact mice and partially blocks orchidectomy-induced trabecular bone loss in male mice [124-127]. Raloxifene ( $\mathrm{Ral}$ ) is approved for the prevention and treatment of osteoporosis in postmenopausal women since it reduces the risk of vertebral fractures by $30-50 \%$ [128]. Its administration increases trabecular bone mass and mineral density in male mice and enhances vertebral trabecular bone mass and femoral cortical bone mass in female mice $[98,127,129]$. More recently, two other SERMs, lasofoxifen (Las) and bazedoxifene (Bza) have been approved in Europe for the treatment or postmenopausal osteoporosis; they decrease the risk of vertebral as well as non-vertebral fractures [130,131]. In mice, whereas Las increases trabecular bone mass in the axial skeleton and both trabecular and cortical bone mass in the appendicular skeleton, Bza only enhances trabecular bone mass in the axial skeleton in both genders $[98,127,129]$. It has been recently shown that ER $\alpha$-AF1 is necessary for the bone estrogenic effects of Ral, Las and Bza in female and male mice $[98,129]$.

\subsection{Mechanical Loading}

Mechanical strains are considered to be a critical regulator of bone homeostasis; they determine bone shape, structure and mass and affect bone remodeling in favor of bone formation. For example, mechanical unloading resulting from weightlessness during space flights is associated with reduced trabecular and cortical bone mineral density and accelerated bone resorption [132]. Thus, during growth, children with moderate physical activity exhibit greater bone mineral content than sedentary children [133].

Regarding the osteogenic effects of mechanical loading, several studies reveal an implication of ER $\alpha$ that would act independently of any ligand. Indeed, the application of mechanical tensions on osteoblast and osteocyte cultures promotes their activation and proliferation via $\mathrm{ER} \alpha[134,135]$. Moreover, a study about the effects of the interactions between $\mathrm{ER} \alpha$ gene polymorphism and physical activity on bone mass modulation in humans suggests that genetic variants of the esr 1 locus could modulate bone tissue mechanosensitivity, supporting a major role of bone cell ER $\alpha$ in bone adaptation to mechanical strains [136].

Several studies showed that ER $\alpha$ is involved in vivo in the osteogenic effects of mechanical strains in a ligand-independent manner $[137,138]$. In female $\mathrm{ER} \alpha^{-/-}$mice, osteogenic response to mechanical loading is reduced in cortical but not trabecular bone compared to WT; conversely, in males, ER $\alpha$ inactivation is associated with increased osteogenic response to mechanical loading in both bone compartments. ER $\beta^{-/-}$female and male mice exhibit increased osteogenic responses to loading in cortical but not trabecular bone [137]. In that respect, ER $\alpha$ and ER $\beta$ seem to have opposite effects and may be in competition for the regulation of bone remodeling by mechanical strains in female mice. Finally, ER $\alpha-\mathrm{AF} 1$ is necessary to mediate osteogenic effects of mechanical loading, whereas ER $\alpha-\mathrm{AF} 2$ is not required in female mice [138]. This again suggests a key role of E2-independent actions of ER $\alpha$, potentially through activation of ER $\alpha$-AF1 that is the target of growth factors. The involvement of ER $\alpha$ in the mechanical strains of bone homeostasis should undoubtedly be further studied in the future to optimize the approaches to fight bone demineralization and the risk of bone fracture.

\section{Conclusions}

In the last ten years, tremendous advances have been made in the knowledge of estrogens and estrogen receptor functions in bone but also in other tissues. The progress in genetic mouse models and pharmacological engineering has allowed us to begin to decipher mechanisms of actions of ERs and should pave the way to optimize selective ER modulation.

Author Contributions: Conception and manuscript drafting: E.N.-E. and A.V. Approving the final version of the manuscript: M.-C.V., C.F., F.T., J.-F.A. and F.L. All authors have read and agreed to the published version of the manuscript.

Funding: This research received no external funding. 
Institutional Review Board Statement: Not applicable.

Informed Consent Statement: Not applicable.

Acknowledgments: The work at INSERM U1048 was supported by INSERM, CHU and Université de Toulouse III, Faculté de Médecine Toulouse-Rangueil, Fondation de France, Fondation pour la Recherche Médicale (FRM), Agence Nationale de la Recherche (ANR) and Conseil Régional MidiPyrénées. V.A. was supported by a grant from the Institut Français pour la Recherche en Odontologie (IFRO). The authors would like to thank the French National Network for Rare Endocrine Diseases FIRENDO (www.firendo.fr)—supported by the Ministry of Health as part of the 3nd National Plan for Rare Diseases (2018-2022) — for providing financial support for the publication of this article.

Conflicts of Interest: The authors declare no conflict of interest.

\section{References}

1. Valéra, M.C.; Fontaine, C.; Dupuis, M.; Noirrit-Esclassan, E.; Vinel, A.; Guillaume, M.; Gourdy, P.; Lenfant, F.; Arnal, J.F. Towards optimization of estrogen receptor modulation in medicine. Pharmacol. Ther. 2018, 189, 123-129. [CrossRef]

2. Cooke, P.S.; Nanjappa, M.K.; Ko, C.; Prins, G.S.; Hess, R.A. Estrogens in Male Physiology. Physiol. Rev. 2017, 97, 995-1043. [CrossRef]

3. Bouillon, R.; Bex, M.; Vanderschueren, D.; Boonen, S. Estrogens Are Essential for Male Pubertal Periosteal Bone Expansion. J. Clin. Endocrinol. Metab. 2004, 89, 6025-6029. [CrossRef]

4. Oldknow, K.J.; Macrae, V.E.; Farquharson, C. Endocrine role of bone: Recent and emerging perspectives beyond osteocalcin. J. Endocrinol. 2015, 225, R1-R19. [CrossRef] [PubMed]

5. Alford, A.I.; Kozloff, K.M.; Hankenson, K.D. Extracellular matrix networks in bone remodeling. Int. J. Biochem. Cell Biol. 2015, 65, 20-31. [CrossRef]

6. $\quad$ Feng, X.; Teitelbaum, S.L. Osteoclasts: New Insights. Bone Res. 2013, 1, 11-26. [PubMed]

7. Ono, T.; Nakashima, T. Recent advances in osteoclast biology. Histochem. Cell Biol. 2018, 149, 325-341. [CrossRef] [PubMed]

8. Komori, T. Regulation of Proliferation, Differentiation and Functions of Osteoblasts by Runx2. Int. J. Mol. Sci. 2019, 20, 1694. [CrossRef]

9. Florencio-Silva, R.; Sasso, G.R.D.S.; Sasso-Cerri, E.; Simões, M.J.; Cerri, P.S. Biology of Bone Tissue: Structure, Function, and Factors That Influence Bone Cells. BioMed Res. Int. 2015, 2015, 421746. [CrossRef]

10. Ducy, P.; Schinke, T.; Karsenty, G. The Osteoblast: A Sophisticated Fibroblast under Central Surveillance. Science 2000, 289, 1501-1504. [CrossRef]

11. Han, Y.; You, X.; Xing, W.; Zhang, Z.; Zou, W. Paracrine and endocrine actions of bone-The functions of secretory proteins from osteoblasts, osteocytes, and osteoclasts. Bone Res. 2018, 6, 1-11. [CrossRef] [PubMed]

12. Dallas, S.L.; Prideaux, M.; Bonewald, L.F. The Osteocyte: An Endocrine Cell . .. and More. Endocr. Rev. 2013, 34, 658-690. [CrossRef]

13. Tresguerres, F.; Torres, J.; López-Quiles, J.; Hernández, G.; Vega, J.; Tresguerres, I. The osteocyte: A multifunctional cell within the bone. Ann. Anat. Anat. Anz. 2020, 227, 151422. [CrossRef] [PubMed]

14. Seeman, E.; Delmas, P. Bone Quality-The Material and Structural Basis of Bone Strenght and Fragility. N. Engl. J. Med. 2006, 354, 2250-2261. [CrossRef] [PubMed]

15. Sims, N.; Martin, J. Coupling the Activities of Bone Formation and Resorption: A Multitude of Signals Within the Basic Multi-cellular Unit. BoneKEy Rep. 2014, 3, 1-10. [CrossRef]

16. Sims, N.A.; Martin, T.J. Osteoclasts Provide Coupling Signals to Osteoblast Lineage Cells Through Multiple Mechanisms. Annu. Rev. Physiol. 2020, 82, 507-529. [CrossRef]

17. Golden, N.H. Bones and Birth Control in Adolescent Girls. J. Pediatr. Adolesc. Gynecol. 2020, 33, 249-254. [CrossRef]

18. Jafari Nasabian, P.; Inglis, J.E.; Reilly, W.; Kelly, O.J.; Ilich, J.Z. Aging human body: Changes in bone, muscle and body fat with con-sequent changes in nutrient intake. J. Endocrinol. 2017, 234, R37-R51. [CrossRef]

19. Ben Kahla, R.; Barkaoui, A.; Merzouki, T. Age-related mechanical strength evolution of trabecular bone under fatigue damage for both genders: Fracture risk evaluation. J. Mech. Behav. Biomed. Mater. 2018, 84, 64-73. [CrossRef]

20. Weaver, C.M.; Gordon, C.M.; Janz, K.F.; Kalkwarf, H.J.; Lappe, J.M.; Lewis, R.; O'Karma, M.; Wallace, T.C.; Zemel, B.S. The National Osteoporosis Foundation's position statement on peak bone mass development and lifestyle factors: A systematic review and implementation recommendations. Osteoporos. Int. 2016, 27, 1281-1386. [CrossRef]

21. Bonjour, J.-P.; Chevalley, T. Pubertal Timing, Bone Acquisition, and Risk of Fracture Throughout Life. Endocr. Rev. 2014, 35, 820-847. [CrossRef] [PubMed]

22. Agas, D.; Lacava, G.; Sabbieti, M.G. Bone and bone marrow disruption by endocrine-active substances. J. Cell. Physiol. 2019, 234, 192-213. [CrossRef]

23. Kirmani, S.; Christen, D.; Van Lenthe, G.H.; Fischer, P.R.; Bouxsein, M.L.; McCready, L.K.; Melton, L.J.; Riggs, B.L.; Amin, S.; Müller, R.; et al. Bone Structure at the Distal Radius During Adolescent Growth. J. Bone Miner. Res. 2009, 24, 1033-1042. [CrossRef]

24. Xue, S.; Kemal, O.; Lu, M.; Lix, L.M.; Leslie, W.D.; Yang, S. Age at attainment of peak bone mineral density and its associated fac-tors: The National Health and Nutrition Examination Survey 2005-2014. Bone 2020, 131, 115163. [CrossRef] 
25. Gabel, L.; Macdonald, H.M.; McKay, H.A. Sex Differences and Growth-Related Adaptations in Bone Microarchitecture, Geome-try, Density, and Strength from Childhood to Early Adulthood: A Mixed Longitudinal HR-pQCT Study. J. Bone Miner. Res. 2017, 32, 250-263. [CrossRef] [PubMed]

26. Laurent, M.; Antonio, L.; Sinnesael, M.; Dubois, V.; Gielen, E.; Classens, F.; Vanderschueren, D. Androgens and estrogens in skeletal sexual dimor-phism. Asian J. Androl. 2014, 16, 213-222. [CrossRef] [PubMed]

27. Connelly, K.J.; Larson, E.A.; Marks, D.L.; Klein, R.F. Neonatal estrogen exposure results in biphasic age-dependent effects on the skeletal development of male mice. Endocrinology 2015, 156, 193-202. [CrossRef] [PubMed]

28. Almeida, M.; Laurent, M.R.; Dubois, V.; Claessens, F.; O’Brien, C.A.; Bouillon, R.; Vanderschueren, D.; Manolagas, S.C. Estrogens and Androgens in Skeletal Physiology and Pathophysiology. Physiol. Rev. 2017, 97, 135-187. [CrossRef] [PubMed]

29. Walsh, J.S.; Henry, Y.M.; Fatayerji, D.; Eastell, R. Lumbar spine peak bone mass and bone turnover in men and women: A longi-tudinal study. Osteoporos. Int. 2009, 20, 355-362. [CrossRef]

30. Iravani, M.; Lagerquist, M.K.; Ohlsson, C.; Sävendahl, L. Regulation of bone growth via ligand-specific activation of estrogen receptor alpha. J. Endocrinol. 2017, 232, 403-410. [CrossRef] [PubMed]

31. Morishima, A.; Grumbach, M.M.; Simpson, E.R.; Fisher, C.; Qin, K. Aromatase deficiency in male and female siblings caused by a novel mutation and the physiological role of estrogens. J. Clin. Endocrinol. Metab. 1995, 80, 3689-3698. [CrossRef] [PubMed]

32. MacGillivray, M.H.; Morishima, A.; Conte, F.; Grumbach, M.; Smith, E.P. Pediatric endocrinology update: An overview. The essen-tial roles of estrogens in pubertal growth, epiphyseal fusion and bone turnover: Lessons from mutations in the genes for aro-matase and the estrogen receptor. Horm. Res. 1998, 49 (Suppl. 1), 2-8. [CrossRef]

33. Smith, E.P.; Boyd, J.; Frank, G.R.; Takahashi, H.; Cohen, R.M.; Specker, B.; Williams, T.C.; Lubahn, D.B.; Korach, K.S. Estrogen Resistance Caused by a Mutation in the Estrogen-Receptor Gene in a Man. N. Engl. J. Med. 1994, 331, 1056-1061. [CrossRef]

34. Rochira, V.; Zirilli, L.; Madeo, B.; Aranda, C.; Caffagni, G.; Fabre, B.; Montangero, V.E.; Roldan, E.J.; Maffei, L.; Carani, C. Skeletal effects of long-term estrogen and testosterone replacement treatment in a man with congenital aromatase deficiency: Evidences of a priming effect of estrogen for sex ster-oids action on bone. Bone 2007, 40, 1662-1668. [CrossRef]

35. Hadji, P.; Colli, E.; Regidor, P.-A. Bone health in estrogen-free contraception. Osteoporos. Int. 2019, 30, 2391-2400. [CrossRef]

36. Manolagas, S.C. From Estrogen-Centric to Aging and Oxidative Stress: A Revised Perspective of the Pathogenesis of Osteoporosis. Endocr. Rev. 2010, 31, 266-300. [CrossRef] [PubMed]

37. Mosekilde, L.; Vestergaard, P.; Rejnmark, L. The Pathogenesis, Treatment and Prevention of Osteoporosis in Men. Drugs 2013, 73, 15-29. [CrossRef]

38. Walsh, J.S.; Paggiosi, M.A.; Eastell, R. Cortical Consolidation of the Radius and Tibia in Young Men and Women. J. Clin. Endocrinol. Metab. 2012, 97, 3342-3348. [CrossRef] [PubMed]

39. Ohlsson, C.; Darelid, A.; Nilsson, M.; Melin, J.; Mellström, D.; Lorentzon, M. Cortical consolidation due to increased mineraliza-tion and endosteal contraction in young adult men: A five-year longitudinal study. J. Clin. Endocrinol. Metab. 2011, 96, 2262-2269. [CrossRef]

40. Bertelloni, S.; Meriggiola, M.C.; Dati, E.; Balsamo, A.; Baroncelli, G.I. Bone Mineral Density in Women Living with Complete An-drogen Insensitivity Syndrome and Intact Testes or Removed Gonads. Sex Dev. 2017, 11, 182-189. [CrossRef]

41. Szeliga, A.; Maciejewska-Jeske, M.; Męczekalski, B. Bone health and evaluation of bone mineral density in patients with prema-ture ovarian insufficiency. Prz. Menop. 2018, 17, 112-116.

42. Lauretani, F.; Bandinelli, S.; E Griswold, M.; Maggio, M.; Semba, R.; Guralnik, J.M.; Ferrucci, L. Longitudinal Changes in BMD and Bone Geometry in a Population-Based Study. J. Bone Miner. Res. 2007, 23, 400-408. [CrossRef]

43. Kovacs, C.S. Maternal Mineral and Bone Metabolism During Pregnancy, Lactation, and Post-Weaning Recovery. Physiol. Rev. 2016, 96, 449-547. [CrossRef] [PubMed]

44. Paton, L.M.; Alexander, J.L.; Nowson, C.; Margerison, C.; Frame, M.G.; Kaymakci, B.; Wark, J.D. Pregnancy and lactation have no long-term deleterious effect on measures of bone mineral in healthy women: A twin study. Am. J. Clin. Nutr. 2003, 77, 707-714. [CrossRef] [PubMed]

45. Anne, T.F.; Pouillès, J.-M.; Drewniak, N.; Laparra, J.; Ribot, C.A.; Dargent-Molina, P. Fracture risk prediction using BMD and clinical risk factors in early postmenopausal women: Sensitivity of the WHO FRAX tool. J. Bone Miner. Res. 2010, 25, 1002-1009. [CrossRef]

46. Winter, E.M.; Ireland, A.; Butterfield, N.C.; Haffner-Luntzer, M.; Horcajada, M.N.; Veldhuis-Vlug, A.G.; Oei, L.; Colaianni, G.; Bonnet, N. Pregnancy and lactation, a challenge for the skeleton. Endocr. Connect. 2020, 9, R143-R157. [CrossRef]

47. Xiao, H.; Zhou, Q.; Niu, G.; Han, G.; Zhang, Z.; Zhang, Q.; Bai, J.; Zhu, X. Association between breastfeeding and osteoporotic hip fracture in women: A dose-response meta-analysis. J. Orthop. Surg. Res. 2020, 15, 1-7. [CrossRef]

48. Polat, S.B.; Evranos, B.; Aydin, C.; Cuhaci, N.; Ersoy, R.; Cakir, B. Effective treatment of severe pregnancy and lactation-related osteoporosis with teriparatide: Case report and review of the literature. Gynecol. Endocrinol. 2015, 31, 522-525. [CrossRef]

49. Yun, K.Y.; Han, S.E.; Kim, S.C.; Kil Joo, J.; Lee, K.S. Pregnancy-related osteoporosis and spinal fractures. Obstet. Gynecol. Sci. 2017, 60, 133-137. [CrossRef]

50. Miyamoto, T.; Miyakoshi, K.; Sato, Y.; Kasuga, Y.; Ikenoue, S.; Miyamoto, K.; Nishiwaki, Y.; Tanaka, M.; Nakamura, M.; Matsumoto, M. Changes in bone metabolic profile associated with pregnancy or lactation. Sci. Rep. 2019, 9, 1-13. [CrossRef]

51. Aspray, T.J.; Hill, T.R. Osteoporosis and the Ageing Skeleton. Macromol. Protein Complexes III Struct. Funct. 2019, 91, 453-476. [CrossRef] 
52. Karlamangla, A.S.; Burnett-Bowie, S.-A.M.; Crandall, C.J. Bone Health During the Menopause Transition and Beyond. Obstet. Gynecol. Clin. N. Am. 2018, 45, 695-708. [CrossRef]

53. Cauley, J.A.; Danielson, M.E.; Greendale, G.A.; Finkelstein, J.S.; Chang, Y.F.; Lo, J.C.; Crandall, C.J.; Neer, R.M.; Ruppert, K.; Meyn, L.; et al. Bone resorption and fracture across the menopausal transition: The Study of Women's Health Across the Nation. Menopause 2012, 19, 1200-1207. [CrossRef] [PubMed]

54. Shieh, A.; Greendale, G.A.; Cauley, J.A.; Karlamangla, A.S. The Association between Fast Increase in Bone Turnover During the Menopause Transition and Subsequent Fracture. J. Clin. Endocrinol. Metab. 2019, 105, e1440-e1448. [CrossRef]

55. Martin-Millan, M.; Almeida, M.; Ambrogini, E.; Han, L.; Zhao, H.; Weinstein, R.S.; Jilka, R.L.; O’Brien, C.A.; Manolagas, S.C. The Estrogen Receptor- $\alpha$ in Osteoclasts Mediates the Protective Effects of Estrogens on Cancellous but Not Cortical Bone. Mol. Endocrinol. 2010, 24, 323-334. [CrossRef]

56. Johnell, O.; Gullberg, B.; Kanis, J.A.; Allander, E.; Elffors, L.; Dequeker, J.; Dilsen, G.; Gennari, C.; Vaz, L.A.; Lyritis, G.; et al. Risk factors for hip fracture in european women: The MEDOS study. J. Bone Miner. Res. 2009, 10, 1802-1815. [CrossRef] [PubMed]

57. Chevalley, T.; Bonjour, J.-P.; Ferrari, S.; Rizzoli, R. Deleterious Effect of Late Menarche on Distal Tibia Microstructure in Healthy 20-Year-Old and Premenopausal Middle-Aged Women. J. Bone Miner. Res. 2009, 24, 144-152. [CrossRef]

58. Vandenput, L.; Kindblom, J.M.; Bygdell, M.; Nethander, M.; Ohlsson, C. Pubertal timing and adult fracture risk in men: A popula-tion-based cohort study. PLoS Med. 2019, 16, e1002986. [CrossRef] [PubMed]

59. Cauley, J.A.; Danielson, M.E.; Jammy, G.R.; Bauer, D.C.; Jackson, R.; Wactawski-Wende, J.; Chlebowski, R.T.; Ensrud, K.E.; Boudreau, R. Sex Steroid Hormones and Fracture in a Multiethnic Cohort of Women: The Women's Health Initiative Study (WHI). J. Clin. Endocrinol. Metab. 2017, 102, 1538-1547. [CrossRef]

60. Cauley, J.A. Estrogen and bone health in men and women. Steroids 2015, 99, 11-15. [CrossRef]

61. Khosla, S.; Monroe, D.G. Regulation of Bone Metabolism by Sex Steroids. Cold Spring Harb. Perspect. Med. 2018, 8, a031211. [CrossRef]

62. Vlot, M.C.; Wiepjes, C.M.; de Jongh, R.T.; T'Sjoen, G.; Heijboer, A.C.; den Heijer, M. Gender-Affirming Hormone Treatment Decreas-es Bone Turnover in Transwomen and Older Transmen. J. Bone Miner. Res. 2019, 34, 1862-1872. [CrossRef] [PubMed]

63. Leblanc, E.S.; Nielson, C.M.; Marshall, L.M.; Lapidus, J.A.; Barrett-Connor, E.; Ensrud, K.E.; Hoffman, A.R.; Laughlin, G.; Ohlsson, C.; Orwoll, E.S.; et al. The Effects of Serum Testosterone, Estradiol, and Sex Hormone Binding Globulin Levels on Fracture Risk in Older Men. J. Clin. Endocrinol. Metab. 2009, 94, 3337-3346. [CrossRef] [PubMed]

64. Macdonald, H.M.; Nishiyama, K.K.; Kang, J.; Hanley, D.A.; Boyd, S.K. Age-related patterns of trabecular and cortical bone loss differ between sexes and skeletal sites: A population-based HR-pQCT study. J. Bone Miner. Res. 2011, 26, 50-62. [CrossRef] [PubMed]

65. Burghardt, A.J.; Kazakia, G.J.; Ramachandran, S.; Link, T.M.; Majumdar, S. Age and Gender Related Differences in the Geometric Properties and Biomechanical Significance of Intra-Cortical Porosity in the Distal Radius and Tibia. J. Bone Miner. Res. 2009, 25, 983-993. [CrossRef]

66. Green, S.; Walter, P.; Kumar, V.; Krust, A.; Bornert, J.-M.; Argos, P.; Chambon, P. Human oestrogen receptor cDNA: Sequence, expression and homology to verb-A. Nat. Cell Biol. 1986, 320, 134-139. [CrossRef]

67. Greene, G.L.; Gilna, P.; Waterfield, M.; Baker, A.; Hort, Y.; Shine, J. Sequence and expression of human estrogen receptor com-plementary DNA. Science 1986, 231, 1150-1154. [CrossRef]

68. Kuiper, G.; Enmark, E.; Pelto-Huikko, M.; Nilsson, S.; Gustafsson, J.-A. Cloning of a Novel Estrogen Receptor Expressed in Rat Prostate and Ovary. Proc. Natl. Acad. Sci. USA 1996, 93, 5925-5930. [CrossRef]

69. Mosselman, S.; Polman, J.; Dijkema, R. ER $\beta$ : Identificatino and Characterization of a Novel Human Estrogen Receptor. FEBS Lett. 1996, 392, 49-53. [CrossRef]

70. Couse, J.F.; Lindzey, J.; Grandien, K.; Gustafsson, J.A.; Korach, K.S. Tissue distribution and quantitative analysis of estrogen receptor-alpha (ERalpha) and estrogen receptor-beta (ERbeta) messenger ribonucleic acid in the wild-type and ERalpha-knockout mouse. Endocrinology 1997, 138, 4613-4621. [CrossRef]

71. Arnal, J.-F.; Lenfant, F.; Metivier, R.; Flouriot, G.; Henrion, D.; Adlanmerini, M.; Fontaine, C.; Gourdy, P.; Chambon, P.; Katzenellenbogen, B.; et al. Membrane and Nuclear Estrogen Receptor Alpha Actions: From Tissue Specificity to Medical Implications. Physiol. Rev. 2017, 97, 1045-1087. [CrossRef]

72. Lindberg, M.K.; Alatalo, S.L.; Halleen, J.M.; Mohan, S.; A Gustafsson, J.; Ohlsson, C. Estrogen receptor specificity in the regulation of the skeleton in female mice. J. Endocrinol. 2001, 171, 229-236. [CrossRef] [PubMed]

73. Movérare, S.; Venken, K.; Eriksson, A.-L.; Andersson, N.; Skrtic, S.; Wergedal, J.; Mohan, S.; Salmon, P.; Bouillon, R.; Gustafsson, J.-A.; et al. Differencial Effects on Bone of Estrogen Receptor $\alpha$ and Androgen Receptor Activation in Orchidectomized Adult Male Mice. Proc. Natl. Acad. Sci. USA 2003, 100, 13573-13578. [CrossRef] [PubMed]

74. Dupont, S.; Krust, A.; Gansmuller, A.; Dierich, A.; Chambon, P.; Mark, M. Effect of single and compound knockouts of estrogen receptors alpha (ERalpha) and beta (ERbeta) on mouse reproductive phenotypes. Development 2000, 127, 4277-4291. [PubMed]

75. Sims, N.A.; Dupont, S.; Krust, A.; Clement-Lacroix, P.; Minet, D.; Resche-Rigon, M.; Gaillard-Kelly, M.; Baron, R. Deletion of estrogen receptors reveals a regulatory role for estrogen receptors-beta in bone remodeling in females but not in males. Bone 2002, 30, 18-25. [CrossRef]

76. Sims, N.A.; Clément-Lacroix, P.; Minet, D.; Fraslon-Vanhulle, C.; Gaillard-Kelly, M.; Resche-Rigon, M.; Baron, R. A functional androgen receptor is not sufficient to allow estradiol to protect bone after gonadectomy in estradiol receptor-deficient mice. J. Clin. Investig. 2003, 111, 1319-1327. [CrossRef] 
77. Vinel, A.; Coudert, A.E.; Buscato, M.; Valera, M.C.; Ostertag, A.; Katzenellenbogen, J.A.; Katzenellenbogen, B.S.; Berdal, A.; Babajko, S.; Arnal, J.F.; et al. Respective role of membrane and nu-clear estrogen receptor (ER) $\alpha$ in the mandible of growing mice: Implications for ER $\alpha$ modulation. J. Bone Miner. Res. 2018, 33, 1520-1531. [CrossRef]

78. Ohlsson, C.; Farman, H.H.; Gustafsson, K.L.; Wu, J.; Henning, P.; Windahl, S.H.; Sjögren, K.; Gustafsson, J.-Å.; Movérare-Skrtic, S.; Lagerquist, M.K. The effects of estradiol are modulated in a tissue-specific manner in mice with inducible inactivation of ER $\alpha$ after sexual maturation. Am. J. Physiol. Metab. 2020, 318, E646-E654. [CrossRef]

79. Idelevich, A.; Baron, R. Brain to bone: What is the contribution of the brain to skeletal homeostasis? Bone 2018, 115, 31-42. [CrossRef]

80. Farman, H.H.; Windahl, S.H.; Westberg, L.; Isaksson, H.; Egecioglu, E.; Schele, E.; Ryberg, H.; Jansson, J.O.; Tuukkanen, J.; Koskela, A.; et al. Female Mice Lacking Estrogen Receptor- $\alpha$ in Hypothalamic Proopiomelanocortin (POMC) Neurons Display Enhanced Estrogenic Response on Cortical Bone Mass. Endocrinology 2016, 157, 3242-3252. [CrossRef]

81. Melville, K.; Kelly, N.; Surita, G.; Buchalter, D.; Schimenti, J.; Main, R.; Ross, F.P.; van der Meulen, M.C. Effects of Deletion of ER $\alpha$ in Osteoblast-Lineage Cells on Bone Mass and Adptation to Mechanical Loading Differ in Female and Male Mice. J. Bone Miner. Res. 2015, 30, 1468-1480. [CrossRef] [PubMed]

82. Määttä, J.A.; Büki, K.G.; Gu, G.; Alanne, M.H.; Vääräniemi, J.; Liljenbäck, H.; Poutanen, M.; Härkönen, P.; Väänänen, K. Inactivation of estrogen receptor $\alpha$ in bone-forming cells induces bone loss in female mice. FASEB J. 2013, 27, 478-488. [CrossRef] [PubMed]

83. Windahl, S.H.; Börjesson, A.E.; Farman, H.H.; Engdahl, C.; Movérare-Skrtic, S.; Sjögren, K.; Lagerquist, M.K.; Kindblom, J.M.; Koskela, A.; Tuukkanen, J.; et al. Estrogen receptor- $\alpha$ in osteocytes is important for trabecular bone formation in male mice. Proc. Natl. Acad. Sci. USA 2013, 110, 2294-2299. [CrossRef] [PubMed]

84. Kondoh, S.; Inoue, K.; Igarashi, K.; Sugizaki, H.; Shirode-Fukuda, Y.; Inoue, E.; Yu, T.; Takeuchi, J.K.; Kanno, J.; Bonewald, L.F.; et al. Estrogen receptor $\alpha$ in osteocytes regulates trabecular bone formation in female mice. Bone 2014, 60, 68-77. [CrossRef]

85. Ucer, S.; Iyer, S.; Bartell, S.M.; Martin-Millan, M.; Han, L.; Kim, H.-N.; Weinstein, R.S.; Jilka, R.L.; O’Brien, C.A.; Almeida, M.; et al. The Effects of Androgens on Murine Cortical Bone Do Not Require AR or ER $\alpha$ Signaling in Osteoblasts and Osteoclasts. J. Bone Miner. Res. 2015, 30, 1138-1149. [CrossRef]

86. Nakamura, T.; Imai, Y.; Matsumoto, T.; Sato, S.; Takeuchi, K.; Igarashi, K.; Harada, Y.; Azuma, Y.; Krust, A.; Yamamoto, Y.; et al. Estrogen Prevents Bone Loss via Estrogen Receptor $\alpha$ and Induction of Fas Ligand in Osteoclasts. Cell 2007, 130, 811-823. [CrossRef]

87. Almeida, M.; Iyer, S.; Martin-Millan, M.; Bartell, S.; Han, L.; Ambrogini, E.; Onal, M.; Xiong, J.; Weinstein, R.; Jilka, R.; et al. Estrogen Receptor- $\alpha$ Signaling in Osteoblast Pro-genitors Stimulates Cortical Bone Accrual. J. Clin. Investig. 2013, 123, 394-404. [CrossRef]

88. Melville, K.M.; Kelly, N.H.; Khan, S.A.; Schimenti, J.C.; Ross, F.P.; Main, R.P.; Van Der Meulen, M.C.H. Female Mice Lacking Estrogen Receptor-Alpha in Osteoblasts Have Compromised Bone Mass and Strength. J. Bone Miner. Res. 2014, 29, 370-379. [CrossRef] [PubMed]

89. Nicks, K.M.; Fujita, K.; Fraser, D.G.; McGregor, U.; Drake, M.T.; McGee-Lawrence, M.E.; Westendorf, J.J.; Monroe, D.G.; Khosla, S. Deletion of Estrogen Receptor Beta in Osteoprogenitor Cells Increases Trabecular but Not Cortical Bone Mass in Female Mice. J. Bone Miner. Res. 2016, 31, 606-614. [CrossRef]

90. Zhang, J.; Link, D.C. Targeting of Mesenchymal Stromal Cells by Cre-Recombinase Transgenes Commonly Used to Target Osteoblast Lineage Cells. J. Bone Miner. Res. 2016, 31, 2001-2007. [CrossRef]

91. Henning, P.; Ohlsson, C.; Engdahl, C.; Farman, H.; Windahl, S.H.; Carlsten, H.; Lagerquist, M.K. The effect of estrogen on bone requires ER $\alpha$ in nonhematopoietic cells but is enhanced by ER $\alpha$ in hematopoietic cells. Am. J. Physiol. Metab. 2014, 307, E589-E595. [CrossRef] [PubMed]

92. Pacifici, R. Role of T cells in ovariectomy induced bone loss-revisited. J. Bone Miner. Res. 2012, 27, 231-239. [CrossRef]

93. Horowitz, M.C.; Fretz, J.A.; Lorenzo, J.A. How B cells influence bone biology in health and disease. Bone 2010, 47, 472-479. [CrossRef]

94. Gustafsson, K.L.; Nilsson, K.H.; Farman, H.H.; Andersson, A.; Lionikaite, V.; Henning, P.; Wu, J.; Windahl, S.H.; Islander, U.; Movérare-Skrtic, S.; et al. ER $\alpha$ expression in T lymphocytes is dispensable for estrogenic effects in bone. J. Endocrinol. 2018, 238, 129-136. [CrossRef] [PubMed]

95. Fujiwara, Y.; Piemontese, M.; Liu, Y.; Thostenson, J.D.; Xiong, J.; O’Brien, C.A. RANKL (Receptor Activator of NFkB Ligand) Pro-duced by Osteocytes Is Required for the Increase in B Cells and Bone Loss Caused by Estrogen Deficiency in Mice. J. Biol. Chem. 2016, 291, 24838-24850. [CrossRef] [PubMed]

96. Billon-Galés, A.; Fontaine, C.; Filipe, C.; Douin-Echinard, V.; Fouque, M.-J.; Flouriot, G.; Gourdy, P.; Lenfant, F.; Laurell, H.; Krust, A.; et al. The transactivating function 1 of estrogen receptor $\alpha$ is dispensable for the vasculoprotective actions of $17 \beta$-estradiol. Proc. Natl. Acad. Sci. USA 2009, 106, 2053-2058. [CrossRef]

97. Billon-Galés, A.; Krust, A.; Fontaine, C.; Abot, A.; Flouriot, G.; Toutain, C.; Berges, H.; Gadeau, A.-P.; Lenfant, F.; Gourdy, P.; et al. Activation function 2 (AF2) of estrogen receptor- $\alpha$ is required for the atheroprotective action of estradiol but not to accelerate endothelial healing. Proc. Natl. Acad. Sci. USA 2011, 108, 13311-13316. [CrossRef]

98. Börjesson, A.E.; Farman, H.H.; Engdahl, C.; Koskela, A.; Sjögren, K.; Kindblom, J.M.; Stubelius, A.; Islander, U.; Carlsten, H.; Antal, M.C.; et al. The role of activation functions 1 and 2 of estrogen receptor- $\alpha$ for the effects of estradiol and selective estrogen receptor modulators in male mice. J. Bone Miner. Res. 2013, 28, 1117-1126. [CrossRef]

99. Börjesson, A.E.; Windahl, S.H.; Lagerquist, M.K.; Engdahl, C.; Frenkel, B.; Movérare-Skrtic, S.; Sjögren, K.; Kindblom, J.M.; Stubelius, A.; Islander, U.; et al. Roles of transactivating func-tions 1 and 2 of estrogen receptor-alpha in bone. Proc. Natl. Acad. Sci. USA 2011, 108, 6288-6293. [CrossRef] 
100. Fontaine, C.; Buscato, M.; Vinel, A.; Giton, F.; Raymond-Letron, I.; Kim, S.H.; Katzenellenbogen, B.S.; Katzenellenbogen, J.A.; Gourdy, P.; Milon, A.; et al. The tissue-specific effects of different $17 \beta$-estradiol doses reveal the key sensitizing role of AF1 domain in ER $\alpha$ activity. Mol. Cell. Endocrinol. 2020, 505, 110741. [CrossRef]

101. Bartell, S.M.; Han, L.; Kim, H.-N.; Kim, S.H.; Katzenellenbogen, J.A.; Katzenellenbogen, B.S.; Chambliss, K.L.; Shaul, P.W.; Roberson, P.K.; Weinstein, R.S.; et al. Non-Nuclear-Initiated Actions of the Estrogen Receptor Protect Cortical Bone Mass. Mol. Endocrinol. 2013, 27, 649-656. [CrossRef]

102. Vinel, A.; Hay, E.; Valera, M.C.; Buscato, M.; Adlanmerini, M.; Guillaume, M.; Cohen-Solal, M.; Ohlsson, C.; Lenfant, F.; Arnal, J.F.; et al. Role of ER $\alpha$ in the Effect of Estradiol on Cancel-lous and Cortical Femoral Bone in Growing Female Mice. Endocrinology 2016, 157, 2533-2544. [CrossRef]

103. Gustafsson, K.L.; Farman, H.; Henning, P.; Lionikaite, V.; Movérare-Skrtic, S.; Wu, J.; Ryberg, H.; Koskela, A.; Gustafsson, J.-Å.; Tuukkanen, J.; et al. The role of membrane ER $\alpha$ signaling in bone and other major estrogen responsive tissues. Sci. Rep. 2016, 6, 29473. [CrossRef]

104. Banerjee, S.; Chambliss, K.L.; Mineo, C.; Shaul, P.W. Recent insights into non-nuclear actions of estrogen receptor alpha. Steroids 2014, 81, 64-69. [CrossRef] [PubMed]

105. Adlanmerini, M.; Solinhac, R.; Abot, A.; Fabre, A.; Raymond-Letron, I.; Guihot, A.L.; Boudou, F.; Sautier, L.; Vessieres, E.; Kim, S.H.; et al. Mutation of the palmitoylation site of estrogen receptor $\alpha$ in vivo reveals tissue-specific roles for membrane versus nuclear actions. Proc. Natl. Acad. Sci. USA 2014, 111, E283-E290. [CrossRef] [PubMed]

106. Pedram, A.; Razandi, M.; Lewis, M.; Hammes, S.; Levin, E.R. Membrane-localized estrogen receptor $\alpha$ is required for normal or-gan development and function. Dev. Cell 2014, 29, 482-490. [CrossRef] [PubMed]

107. Adlanmerini, M.; Fébrissy, C.; Zahreddine, R.; Vessières, E.; Buscato, M.; Solinhac, R.; Favre, J.; Anquetil, T.; Guilhot, A.L.; Boudou, F.; et al. Mutation of Arginine 264 on ER $\alpha$ (Estrogen Receptor Alpha) Selectively Abrogates the Rapid Signaling of Estradiol in the Endothelium Without Altering Fertili-ty. Arterioscler. Thromb. Vasc. Biol. 2020, 40, 2143-2158. [CrossRef]

108. Gustafsson, K.L.; Farman, H.H.; Nilsson, K.H.; Henning, P.; Movérare-Skrtic, S.; Lionikaite, V.; Lawenius, L.; Engdahl, C.; Ohlsson, C.; Lagerquist, M.K. Arginine site 264 in murine estrogen receptor alpha is dispensable for the regulation of the skeleton. Am. J. Physiol. Metab. 2020. [CrossRef]

109. Abot, A.; Fontaine, C.; Buscato, M.; Solinhac, R.; Flouriot, G.; Fabre, A.; Drougard, A.; Rajan, S.; Laine, M.; Milon, A.; et al. The uterine and vascular actions of estetrol delineate a distinctive profile of estrogen receptor $\alpha$ modulation, uncoupling nuclear and membrane activation. EMBO Mol. Med. 2014, 6, 1328-1346. [CrossRef]

110. Benoit, T.; Valera, M.-C.; Fontaine, C.; Buscato, M.; Lenfant, F.; Raymond-Letron, I.; Tremollieres, F.; Soulie, M.; Foidart, J.-M.; Gamé, X.; et al. Estetrol, a Fetal Selective Estrogen Receptor Modulator, Acts on the Vagina of Mice through Nuclear Estrogen Receptor $\alpha$ Activation. Am. J. Pathol. 2017, 187, 2499-2507. [CrossRef]

111. Valéra, M.-C.; Noirrit, E.; Dupuis, M.; Fontaine, C.; Lenfant, F.; Briaux, A.; Cabou, C.; Garcia, C.; Lairez, O.; Foidart, J.-M.; et al. Effect of estetrol, a selective nuclear estrogen receptor modulator, in mouse models of arterial and venous thrombosis. Mol. Cell. Endocrinol. 2018, 477, 132-139. [CrossRef] [PubMed]

112. Coelingh Bennink, H.J.; Holinka, C.F.; Diczfalusy, E. Estetrol review: Profile and potential clinical applications. Climacteric 2008, 11 (Suppl. 1), 47-58. [CrossRef]

113. Coelingh Bennink, H.J.; Heegaard, A.M.; Visser, M.; Holinka, C.F.; Christiansen, C. Oral bioavailability and bone-sparing effects of estetrol in an osteoporosis model. Climacteric 2008, 11 (Suppl. 1), 2-14. [CrossRef]

114. Coelingh Bennink, H.J.T.; Verhoeven, C.; Zimmerman, Y.; Visser, M.; Foidart, J.M.; Gemzell-Danielsson, K. Pharmacodynamic effects of the fetal estrogen estetrol in postmenopausal women: Results from a multiple-rising-dose study. Menopause 2017, 24, 677-685. [CrossRef] [PubMed]

115. Coelingh Bennink, H.J.; Verhoeven, C.; Zimmerman, Y.; Visser, M.; Foidart, J.M.; Gemzell-Danielsson, K. Clinical effects of the fetal estrogen estetrol in a multiple-rising-dose study in postmenopausal women. Maturitas 2016, 91, 93-100. [CrossRef] [PubMed]

116. Coelingh Bennink, H.J.T.; Zimmerman, Y.; Verhoeven, C.; Dutman, A.E.; Mensinga, T.; Kluft, C.; Reisman, Y.; Debruyne, F.M.J. A Dose-Escalating Study with the Fetal Estrogen Estetrol in Healthy Men. J. Clin. Endocrinol. Metab. 2018, 103, 3239-3249. [CrossRef] [PubMed]

117. Harrington, W.; Sung Hoon, K.; Funk, C.; Madak-Erdogan, Z.; Schiff, R.; Katzenellenbogen, J.; Katzenellenbogen, B. Estrogen Dendrimer Conju-gates that Preferentially Activate Extranuclear, Nongenomic Versus Genomic Pathways of Estrogen Action. Mol. Endo-Crinol. 2006, 20, 491-502. [CrossRef] [PubMed]

118. Chambliss, K.L.; Wu, Q.; Oltmann, S.; Konaniah, E.S.; Umetani, M.; Korach, K.S.; Thomas, G.; Minea, C.; Yyhanna, I.; Sung Hoon, K.; et al. Non-nuclear estrogen receptor alpha signal-ing promotes cardiovascular protection but not uterine or breast cancer growth in mice. J. Clin. Investig. 2010, 120, 2319-3230. [CrossRef]

119. Farman, H.H.; Wu, J.; Gustafsson, K.L.; Windahl, S.H.; Kim, S.H.; A Katzenellenbogen, J.; Ohlsson, C.; Lagerquist, M.K. Extra-nuclear effects of estrogen on cortical bone in males require ER $\alpha$ AF-1. J. Mol. Endocrinol. 2017, 58, 105-111. [CrossRef]

120. Madak-Erdogan, Z.; Kim, S.H.; Gong, P.; Zhao, Y.C.; Zhang, H.; Chambliss, K.L.; Carlson, K.E.; Mayne, C.G.; Shaul, P.W.; Korach, K.S.; et al. Design of pathway preferential estrogens that provide beneficial metabolic and vascular effects without stimulating reproductive tissues. Sci. Signal. 2016, 9, ra53. [CrossRef] 
121. Farman, H.H.; Gustafsson, K.L.; Henning, P.; Grahnemo, L.; Lionikaite, V.; Movérare-Skrtic, S.; Wu, J.; Ryberg, H.; Koskela, A.; Tuukkanen, J.; et al. Membrane estrogen receptor $\alpha$ is essential for estrogen signaling in the male skeleton. J. Endocrinol. 2018, 239, 303-312. [CrossRef]

122. Riggs, L.; Hartmann, L. Selective Estrogen-Receptor Modulators: Mechanisms of Action and Application to Clinical Practice. N. Engl. J. Med. 2003, 348, 618-629. [CrossRef]

123. Pinkerton, J.V.; Conner, E.A. Beyond estrogen: Advances in tissue selective estrogen complexes and selective estrogen receptor modulators. Climacteric 2019, 22, 140-147. [CrossRef] [PubMed]

124. Zhong, Z.A.; Sun, W.; Chen, H.; Zhang, H.; Lay, Y.-A.E.; Lane, N.E.; Yao, W. Optimizing tamoxifen-inducible Cre/loxp system to reduce tamoxifen effect on bone turnover in long bones of young mice. Bone 2015, 81, 614-619. [CrossRef]

125. Starnes, L.M.; Downey, C.M.; Boyd, S.K.; Jirik, F.R. Increased bone mass in male and female mice following tamoxifen administration. Genesis 2007, 45, 229-235. [CrossRef]

126. Jardí, F.; Laurent, M.R.; Dubois, V.; Khalil, R.; Deboel, L.; Schollaert, D.; Bosch, L.V.D.; Decallonne, B.; Carmeliet, G.; Claessens, F.; et al. A shortened tamoxifen induction scheme to induce CreER recombinase without side effects on the male mouse skeleton. Mol. Cell. Endocrinol. 2017, 452, 57-63. [CrossRef] [PubMed]

127. Sato, Y.; Tando, T.; Morita, M.; Miyamoto, K.; Kobayashi, T.; Watanabe, R.; Oike, T.; Matsumoto, M.; Nakamura, M.; Miyamoto, T. Selective estrogen receptor modulators and the vitamin $\mathrm{D}$ analogue eldecalcitol block bone loss in male osteoporosis. Biochem. Biophys. Res. Commun. 2017, 482, 1430-1436. [CrossRef] [PubMed]

128. Kanis, J.A.; Cooper, C.; Rizzoli, R.; Reginster, J.Y. (IOF) SABotESfCaEAoOEatCoSAaNSotIOF. European guidance for the diagno-sis and management of osteoporosis in postmenopausal women. Osteoporos. Int. 2019, 30, 3-44. [CrossRef]

129. Börjesson, A.E.; Farman, H.H.; Movérare-Skrtic, S.; Engdahl, C.; Antal, M.C.; Koskela, A.; Tuukkanen, J.; Carlsten, H.; Krust, A.; Chambon, P.; et al. SERMs have substance-specific ef-fects on bone, and these effects are mediated via Er $\alpha$ AF- 1 in female mice. Am. J. Physiol. Endocrinol. Metab. 2016, 310, E912-E918. [CrossRef]

130. Palacios, S.; Silverman, S.L.; de Villiers, T.J.; Levine, A.B.; Goemaere, S.; Brown, J.P.; De Cicco Nardone, F.; Williams, R.; Hines, T.L.; Mirkin, S.; et al. A 7-year randomized, placebo-controlled trial assessing the long-term efficacy and safety of bazedoxifene in postmenopausal women with osteoporosis: Effects on bone density and fracture. Menopause 2015, 22, 806-813. [CrossRef]

131. Cummings, S.R.; Ensrud, K.; Delmas, P.D.; LaCroix, A.Z.; Vukicevic, S.; Reid, D.M.; Goldstein, S.; Sriram, U.; Lee, A.; Thompson, J.; et al. Lasofoxifene in postmenopausal women with osteoporosis. N. Engl. J. Med. 2010, 362, 686-696. [CrossRef] [PubMed]

132. Vico, L.; Collet, P.; Guignandon, A.; Lafage-Proust, M.-H.; Thomas, T.; Rehailia, M.; Alexandre, C. Effects of long-term microgravity exposure on cancellous and cortical weight-bearing bones of cosmonauts. Lancet 2000, 355, 1607-1611. [CrossRef]

133. Klentrou, P. Influence of Exercise and Training on Critical Stages of Bone Growth and Development. Pediatr. Exerc. Sci. 2016, 28, 178-186. [CrossRef] [PubMed]

134. Aguirre, J.I.; Plotkin, L.I.; Gortazar, A.R.; Millan, M.M.; O’Brien, C.A.; Manolagas, S.C.; Bellido, T. A Novel Ligand-independent Function of the Estrogen Receptor Is Essential for Osteocyte and Osteoblast Mechanotransduction. J. Biol. Chem. 2007, 282, 25501-25508. [CrossRef] [PubMed]

135. Galea, G.L.; Meakin, L.B.; Sugiyama, T.; Zebda, N.; Sunters, A.; Taipaleenmaki, H.; Stein, G.S.; Van Wijnen, A.J.; Lanyon, L.E.; Price, J.S. Estrogen Receptor $\alpha$ Mediates Proliferation of Osteoblastic Cells Stimulated by Estrogen and Mechanical Strain, but Their Acute Down-regulation of the Wnt Antagonist Sost Is Mediated by Estrogen Receptor $\beta$. J. Biol. Chem. 2013, 288, 9035-9048. [CrossRef]

136. Suuriniemi, M.; Mahonen, A.; Kovanen, V.; Alén, M.; Lyytikäinen, A.; Wang, Q.; Kröger, H.; Cheng, S. Association Between Exercise and Pubertal BMD Is Modulated by Estrogen Receptor $\alpha$ Genotype. J. Bone Miner. Res. 2004, 19, 1758-1765. [CrossRef] [PubMed]

137. Saxon, L.K.; Galea, G.; Meakin, L.; Price, J.; Lanyon, L.E. Estrogen Receptors $\alpha$ and $\beta$ Have Different Gender-Dependent Effects on the Adaptive Responses to Load Bearing in Cancellous and Cortical Bone. Endocrinology 2012, 153, 2254-2266. [CrossRef]

138. Windahl, S.; Saxon, L.; Börjesson, A.; Lagerquist, M.; Frenkel, B.; Henning, P.; Lerner, U.; Galea, G.; Meakin, L.; Engdahl, C.; et al. Estrogen Receptor- $\alpha$ Is Required of the Osteo-genic Response to Mechanical Loading in a Ligand-Independant Manner Involving Its Activatin Function 1 but Not 2. J. Bone Miner. Res. 2013, 28, 291-301. [CrossRef] 